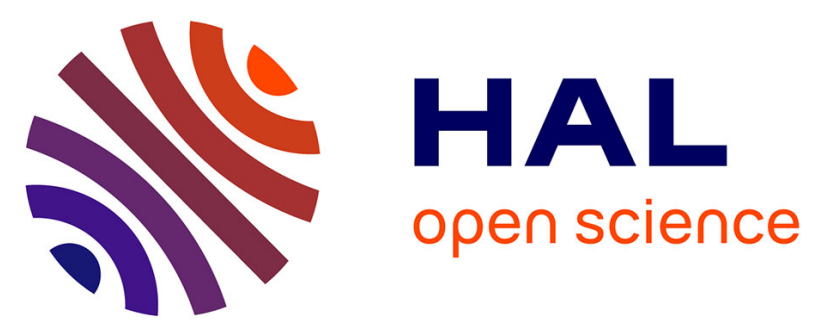

\title{
A simple groundwater balance tool to evaluate the three-dimensional specific yield and the two-dimensional recharge: application to a deeply weathered crystalline aquifer in southern India
}

Syed Adil Mizan, Benoît Dewandel, Adrien Selles, Shakeel Ahmed, Yvan

Caballero

\section{To cite this version:}

Syed Adil Mizan, Benoît Dewandel, Adrien Selles, Shakeel Ahmed, Yvan Caballero. A simple groundwater balance tool to evaluate the three-dimensional specific yield and the two-dimensional recharge: application to a deeply weathered crystalline aquifer in southern India. Hydrogeology Journal, 2019, 10.1007/s10040-019-02026-8 . hal-02289380

\section{HAL Id: hal-02289380 https: / hal-brgm.archives-ouvertes.fr/hal-02289380}

Submitted on 16 Sep 2019

HAL is a multi-disciplinary open access archive for the deposit and dissemination of scientific research documents, whether they are published or not. The documents may come from teaching and research institutions in France or abroad, or from public or private research centers.
L'archive ouverte pluridisciplinaire HAL, est destinée au dépôt et à la diffusion de documents scientifiques de niveau recherche, publiés ou non, émanant des établissements d'enseignement et de recherche français ou étrangers, des laboratoires publics ou privés. 
1 A simple groundwater balance tool to evaluate the three-dimensional 2 specific yield and the two-dimensional recharge: application to a deeply 3 weathered crystalline aquifer in southern India.

4 Syed Adil Mizan ${ }^{1}$, Benoit Dewandel ${ }^{2}$, Adrien Selles ${ }^{3}$, Shakeel Ahmed ${ }^{1}$, Yvan Caballero ${ }^{2}$

$5{ }^{1}$ Indo-French center for groundwater research, CSIR-NGRI, Hyderabad, India.

$6 \quad{ }^{2}$ BRGM, D3E/NRE, 1039 rue de pinville, Montpellier, France.

$7 \quad{ }^{3}$ BRGM Unit, IFCGR, CSIR-NGRI, Hyderabad, India.

8 Corresponding author: Syed Adil Mizan, Email: adilmizan3@gmail.com 9

Abstract: Crystalline aquifers are among the most complex groundwater systems, requiring adequate methods for realistic characterization and suitable techniques for improving the long-term management of groundwater resources. A tool is needed that can assess the aquifer hydrodynamic parameters cost-effectively. A model is presented, based on a groundwaterbudget equation and water-table fluctuation method, which combines the upscaling and the regionalization of aquifer parameters, in particular specific yield $\left(S_{\mathrm{y}}\right)$ in three dimensions (3D) and the recharge in two dimensions (2-D) from rainfall at watershed scale. The tool was tested and validated on the $53-\mathrm{km}^{2}$ Maheshwaram watershed, southern India, at a $685 \mathrm{~m} \times$ $685 \mathrm{~m}$ cell scale, and was calibrated on seasonal groundwater levels from 2011 to 2016. Comparison between computed and observed levels shows an absolute residual mean and a root mean square error of $1.17 \mathrm{~m}$ and $1.8 \mathrm{~m}$, respectively, showing the robustness of the model. $S_{\mathrm{y}}$ ranges from 0.3 to $5 \%$ (mean $1.4 \%$ ), which is in good agreement with previous studies. The annual recharge from rainfall is also in good agreement with earlier studies and, despite its strong annual variability (16 to $199 \mathrm{~mm} / \mathrm{y}$ ) at watershed scale, it shows that spatial recharge is clearly controlled by spatial structure, from one year to another. Groundwater levels were also forecasted from 2020 to 2039 based on the climate and groundwater abstraction scenarios. The results show severe water-level depletion around 2024-2026 but it would be more stable in the future (after 2030) because of a lower frequency of low-rainfall monsoons.

Keywords: Crystalline rock, India, Specific yield, Recharge 


\section{INTRODUCTION}

India has 27 million hectares of farmland, a considerable area of which (21 million ha) is irrigated by groundwater rather than by surface water (Shah 2007). Development of this irrigation (surface and groundwater) occurred in the 1970s with the start of the Green Revolution. Consequently, the number of bore-wells increased sharply from less than 1 million in 1960 to over 19 million in 2000 and more than 20 million by 2007 (Shah 2007). As a result, especially in the crystalline rock and semi-arid areas, which cover about two-thirds of the country, groundwater resources are under permanent stress and are often overexploited (Shah 2007) because of the large amount of abstraction for irrigation. Therefore, it is urgent to adopt groundwater abstraction based on a better knowledge of the aquifer system and the availability of the resource.

In South India, most of the aquifers are constituted by crystalline aquifers, i.e. in granitic and metamorphic rocks, and are considered as highly heterogeneous. Recent studies in African, European and Indian basement areas have increased knowledge and proposed methods for improving groundwater management (Omorinbola, 1982, 1983; Wright, 1992; Chilton and Foster, 1995; Owoade, 1995; Wyns et al.,1999; Taylor and Howard, 2000; Maréchal et al., 2004; Dewandel et al., 2006; Kràsy and Sharp, 2007; Maréchal et al., 2007, Courtois et al., 2008; 2010; Dewandel et al., 2010; Lachassagne et al. 2011, Mizan et al., 2019, etc.). These studies showed that, when regional deep weathering processes affect such hard rocks, they can be considered as a two-layered aquifer system. The two layers are directly connected (there is no impervious or semi-pervious layer between them). In this case, aquifers consist of two main sub-parallel hydrogeological layers, an upper saprolite layer of porous clayey-sandy material with low permeability, and a lower fractured layer, characterized by a dense horizontal fracturing in the first few meters, followed by a rapid 
depth-decrease of the fracture density. This last layer, with low porosity, assumes the transmissive function of the aquifer. The underlying layer is characterized by lower porosity $(K)$ but higher permeability because of the fracture (average $K$ is about $10^{-5} \mathrm{~m} / \mathrm{s}$ and porosity 0.005; see Lachassagne et al., 2011, Dewandel et al., 2006 \& Marechal et al., 2004).

Based on the described multi-layer property and the combined use of a water-tablefluctuation method and groundwater budget, Dewandel et al. (2010) developed a model for testing groundwater scenarios under variable agro-climatic conditions. However, the results of this model, i.e. the reproduction of water-table level fluctuations and the seasonal drying up of bore wells, were applicable at small watershed scale only, discouraging the use of such a model over an area larger than a few tens of $\mathrm{km}^{2}$. Dewandel et al. $(2012,2017)$ then developed methods for upscaling and regionalizing the aquifer properties of a crystalline aquifer, such as specific yield and hydraulic conductivity. For several granitic aquifers in India (50 to $1000 \mathrm{~km}^{2}$ ), they showed that where an aquifer is intensively pumped horizontal groundwater fluxes within the aquifer can be neglected compared to the vertical fluxes (pumping and recharge) above a certain cell size $\left(0.5\right.$ to $\left.1.5 \mathrm{~km}^{2}\right)$, depending on the studied aquifer. This cell-size threshold is controlled by the spatial distributions of both aquifer properties and pumping (Dewandel et al., 2012). Here and similarly to Dewandel et al. (2010), a column model is developed and applied independently to each aquifer cell, thus providing a useful tool for improving groundwater management at a 2-D spatial scale. The basic requirement for using this model is that the aquifer should be unconfined (regardless of rock type), intensively pumped, and that non-monsoon and monsoon seasons should be well differentiated. In spite of the hydrogeological complexity in crystalline rock aquifers, a simple method, which recalled here, provides estimates of specific yield and recharge spatially. However, it does not require spatial distribution of hydraulic conductivity because of the negligible effect of horizontal groundwater flux compared to vertical ones (pumping \& 
recharge) from a particular cell size (Dewandel et al., 2012), as for a classic numerical model, which is a topic of large uncertainty, particularly in crystalline aquifers.

The semi-arid Maheshwaram watershed $\left(53 \mathrm{~km}^{2}\right)$ in southern India was taken as a benchmark (standard) crystalline aquifer system (Fig. 1). This watershed is representative of a peri-urban Indian catchment, in the transition from rural to peri-urban activities with groundwater overexploitation issues. The cell size chosen, $685 \mathrm{~m} \times 685 \mathrm{~m}$, is based on previous studies in the area (Dewandel et al., 2012) and allows a good spatial discretization of the area (113 cells). This size is above the threshold size from which horizontal fluxes can be neglected compared to vertical ones (Dewandel et al., 2012). The modeling was conducted with data from 2011 to 2016, with the dual objective of reproducing observed detailed watertable maps and of evaluating the coherence of other model results, such as recharge and specific yield models. Once the model was validated, it was used for forecasting groundwater-level, including scenarios with changing patterns of groundwater abstraction and a rainfall model (regional downscaled rainfall data issued from climate scenarios, Vigaud et al., 2013).

The aim of this paper is to present a simple, cost-efficient spatial groundwater balance model using upscaling and regionalization techniques for aquifer properties in crystalline aquifers. In-spite of the complexity in crystalline aquifers, this model proposes a 3dimensional distribution of specific yield $\left(S_{\mathrm{y}}\right)$ and 2-dimensional recharge $(R)$ estimation which may also be very useful to reduce the biasness of numerical models. By combining the output of the model with forecasted rainfall, this model is also able to project water level scenarios for the coming decades.

\section{FIELD DATA}

\subsection{Topography and Climate}


104 The Maheshwaram watershed $\left(53 \mathrm{~km}^{2}\right)$ is located $40 \mathrm{~km}$ south of Hyderabad (Fig. 1). The area has a relatively flat topography with elevation ranging from 590 to $670 \mathrm{~m}$ above mean sea level and without perennial streams. According to the Koppen classification, this region falls within the BSh (hot semi-arid) climate type. The aridity index of this area is $\sim 0.42$ (Annual potential evapotranspiration $1800 \mathrm{~mm}$ and annual mean precipitation $750 \mathrm{~mm}$; Dewandel et al., 2010). The Kharif (monsoon) season lasts from June to October and the Rabi (non-monsoon) season is from November to May. Almost $90 \%$ of mean annual rainfall is received during the Kharif. The mean annual temperature of the area is $26{ }^{\circ} \mathrm{C}$, but in summer it can rise to $45^{\circ} \mathrm{C}$. The area is rural and populated by about 65,000 inhabitants (Indian Census, 2011).

\subsection{Geology}

The study area is underlain by Archean biotite granite that is locally intruded by small bodies of leucocratic granite (Dewandel et al., 2006; Fig. 1b). The biotite granite is slightly metamorphosed (slightly into orthogneissic granite) and foliated. Intrusive leucocratic granite has a lower biotite content, infra-centimetric grain size with poor porphyritic K-feldspars, and forms small boulder-covered hills in the landscape. Some kilometer-size dolerite dikes and quartz veins intrude the granites. There are no important textural changes at watershed scale and variation in the degree of weathering and also type of rock does not show any significant difference in term of specific yield and hydraulic conductivity (Dewandel et al., 2012).The rocks are affected by deep in-situ weathering resulting from multiphase weathering-erosion processes (Dewandel et al., 2006). Typically, the weathering profile shows from top to bottom (Fig. 2; Dewandel et al., 2006);

- A thin layer of red soil $(10-40 \mathrm{~cm})$;

- A 1-3 m thick sandy regolith, locally capped by a lateritic crust $<50 \mathrm{~cm}$ thick; 
- A 10-15 m thick layer of laminated saprolite with a penetrative millimeter-spaced horizontal laminated structure and an unusual network of mainly sub-horizontal and some sub-vertical fractures, partially filled by clayey minerals;

- Fractured granite occupies the next 15-20 m, with weathered granite and some clay partially filling up decametre-wide sub-horizontal and sub-vertical fractures, the whole constituting the bottom layer of weathering profile. The density a fracture rapidly decreases with depth;

- Below, the granite is not fractured and is not considered as an aquifer (Dewandel et al., 2006, 2012; Maréchal et al., 2006).

\subsection{Groundwater abstraction}

Irrigation in the area totally depends on groundwater resources. Over 1000 bore wells are used for the irrigation of rice, vegetables and orchards, but $90 \%$ of the groundwater is used for rice growing (Maréchal et al., 2006; Dewandel et al., 2010). Plots are irrigated by flooding (rice and vegetables) and drip irrigation (orchards). Well discharge rates range from 0.3 to $42 \mathrm{~m}^{3} /$ hour, but $40 \%$ are below $5 \mathrm{~m}^{3} /$ hour (Dewandel et al., 2012).

Land use was evaluated over the Rabi (non-monsoon) seasons of November 2007 to May 2008 and November 2013 to May 2014, for estimating the corresponding groundwater abstraction. Irrigated rice areas cover around $3.7 \%$ of the watershed, followed by orchards, $2.5 \%$, and vegetables, $0.8 \%$; the rest of the area is covered by constructions, forest, and barren rocky areas. Crops are cultivated year-round. During Rabi season, crop irrigation totally depends on groundwater resources because of the absence of perennial surface water and as more than $90 \%$ rainfall occurs during the monsoon. Crops are also irrigated during monsoon with groundwater, but at a lower rate (Maréchal et al., 2006; Dewandel et al., 2008). Field observations on crop cultivation and irrigation were collected from farmers to 
get reliable data on crop calendars and stages, as well as on watering techniques, frequency and rates of irrigation. Daily water inputs by pumping for each crop at parcel scale are documented in Dewandel et al. (2008). The mean daily water input for rice during the nonmonsoon season is $15 \mathrm{~mm}$, whereas during the wet season it is only $10 \mathrm{~mm}$, the rest coming from rain. For vegetables and orchards, the numbers are $7 \mathrm{~mm} /$ day and $4.9 \mathrm{~mm} /$ day respectively, independently of the season. The combination of land use, daily water input for each crop, and number of days of each crop cultivation, allows computing the seasonal groundwater abstraction in the watershed. Groundwater also contributes to domestic use, the amount of abstraction is based on census data (Indian census, 2011; 65,125 inhabitants) and daily groundwater consumption per person (25 liters/day; from field survey). Population has been considered as constant for every year.

The watershed area does not have a stationary land-use pattern; during the monsoon season, farmers adopt the size of irrigated lands according to the rainfall amount. Precipitation and pumping data for the 2001-2004 non-monsoon seasons (Dewandel et al., 2010) and estimated pumping data from land-use maps (Nov 2007-May 2008 and Nov 2013May 2014) show an empirical linear relationship at watershed scale (Fig. 3a). As data on pumping and land use were not available for the non-monsoon seasons between Nov 2007 May 2008 and Nov 2015 - May 2016, this relationship was used to fill these pumping-data gaps (Fig. 3b). In India, there is no regulation on groundwater abstraction. As a consequence, farmers pumped when there is water in their wells (i.e. good recharge from the enough rainfall) and reduce pumping when availability of water is low. Therefore, when there is enough water, they can irrigate large scale areas, and when bore wells yields decrease, they cultivate smaller areas. This is probably why there is this non-intuitive relationship between groundwater pumping and rainfall. Figure $3 \mathrm{c}$ shows how pumping ratios for two nonmonsoon (dry) seasons (Nov 2013-May 2014 and Nov 2007-May 2008) vary at the 
watershed scale. In most cells (each of $685 \mathrm{~m} \times 685 \mathrm{~m}$ ), the ratio is close to the mean variation (1.5) at the watershed scale, suggesting that pumping variations between two consecutive non-monsoon seasons are the same almost everywhere in the watershed. This allows the use, reasonable at cell scale, of the empirical relationship defined on Figure $3 a$. During monsoon (rainy) seasons, the mean pumping at watershed scale is about two-thirds of that during non-monsoon seasons (Dewandel et al., 2010). This ratio was applied at cell scale for the estimation of pumping during the June to October monsoon seasons from 2011 to 2015 , because of the lack of both pumping and land-use data. Figure $3 \mathrm{~d}$ shows the mean groundwater abstraction spatially at watershed scale for all November-to-May non-monsoon seasons between 2011 and 2016; abstraction varies from 0 (no irrigation) to $300 \mathrm{~mm}$ (watershed mean: $80 \mathrm{~mm}$ ). The water table elevation was also mapped (average of all nonmonsoon seasons) and was particularly affected by pumping.

\subsection{Irrigation return flow}

Irrigation return flow (IRF) was calculated based on the return flow coefficients of each crop type $\left(\mathrm{IRF}=Q / C_{\mathrm{f}}\right), Q$ and $C_{\mathrm{f}}$ are the groundwater abstraction rate and the return flow coefficient, respectively. $C_{\mathrm{f}}$ values for each crop are documented in Dewandel et al., (2008) and Maréchal et al. (2006), and are listed in Table 1. Each coefficient was applied to the corresponding groundwater use, which allows for estimating net groundwater abstraction. An IRF value of nil $(\mathrm{IRF}=0)$ was used for orchards because of the use of drip irrigation.

\subsection{Water level}

Recorded water-level measurements show well-identified seasonal fluctuations because of water percolation during the monsoon through a thick unsaturated zone as well as small fluctuations due to pumping cycles (e.g. Maréchal et al., 2006). The monsoon season, when the water level may rise several metres due to natural recharge from rainfall, is followed by 
the non-monsoon season when the water level drops due to intensive groundwater pumping

202

203

204 (Fig. 3b). Delay between the rainfall event and water level rise is generally few days or weeks after the start of monsoon. However, here the model works at a seasonal time-step (Rabi \& Kharif), largely greater than usually used for hydrogeological timing.

The water-table elevation maps were based on groundwater-level measurements in 85 to 110 observation wells after monsoon seasons (November 2011 to November 2015) and at the end of non-monsoon seasons (May 2011 till May 2016). The number of observation wells are different because some wells have been abandoned with time. Water levels are deep (15$17 \mathrm{~m}$ below ground level on average). They are mainly situated within the fractured layer, more or less parallel to the topographic surface, and are severely impacted by pumping (Fig. 3d). Water-table elevation maps from October 2011 to May 2016 (one per season; 10 maps) were produced with standard kriging techniques (variographic analysis and kriging for data interpolation).

\section{METHODS}

\subsection{Groundwater budget}

The model is based on combining the water-table fluctuation method (WTF) and a groundwater-budget technique (Maréchal et al., 2003, Dewandel et al., 2010). As the tool focuses on groundwater flux only — it is based on groundwater budget - there is no need for estimating recharge directly from rainfall, or from evapotranspiration. This is a serious advantage when dealing with crystalline rock aquifers, particularly in semi-arid climates, where such estimates can be a source of large uncertainty.

The basic groundwater-budget equation is (e.g. Schicht and Walton, 1961; Maréchal et al., 2006):

$$
R+\mathrm{IRF}+q_{\text {in }}=Q+E+q_{\text {out }}+q_{\mathrm{bf}}+\Delta S
$$


where $R$ is total groundwater recharge, IRF irrigation return flow, $q_{\text {in }}$ and $q_{\text {out }}$ horizontal groundwater inflow and outflow, $Q$ groundwater abstraction by pumping, $E$ evaporation/evapotranspiration from the water table (Evaporation/Evapotranspiration from the bare or vegetated ground varied with different groundwater level; Zhang et al., 2019 \& Shokri et al., 2011), $q_{\text {bf }}$ base flow (groundwater discharge to stream or spring), and $\Delta S$ change in groundwater storage. All budget component units are in millimetres (mm).

Groundwater storage is computed with the WTF method, which is the product of specific yield $\left(S_{\mathrm{y}}\right)$ and water-level fluctuation $(\Delta h)$ :

$$
\Delta S=S_{\mathrm{y}} \times \Delta h
$$

Some terms in Equation 1 can be neglected. As the water table depth increased, cumulative evaporation/evapotranspiration decreased (Zhang et al., 2019). A similar observation was made by Shokri et al., (2011) for porous media. Therefore, due to deep water levels in the area (on average $15-17 \mathrm{~m}$ ), $E$ is a very small component of the budget in the watershed, typically less than $1 \mathrm{~mm} / \mathrm{year}$ (Maréchal et al., 2006; Dewandel et al., 2010) and can be neglected. In addition, the absence of perennial stream- and spring flow because of the disconnection between the water table and the drainage network, leads to nil $q_{\mathrm{bf}}$. Therefore, Equation 1 can be simplified, and becomes:

$$
R+\mathrm{IRF}+q_{\text {in }}=Q+\Delta S+q_{\text {out }}
$$

Because water levels are controlled by the periodicity of the monsoon $(R=0$ during non-monsoon (dry) season), Eq. 3 has been used twice in a hydrological year, during both monsoon (rainy- Kharif) and non-monsoon (dry- Rabi) seasons. In the non-monsoon (dry) season, recharge $(R)$ is assumed nil, and combining Eq. 2 and 3 leads to estimation of the specific yield (Maréchal et al., 2006):

$$
S_{\mathrm{y}}=\left(Q_{\text {Rabi }}-\mathrm{IRF}_{\text {Rabi }}+q_{\text {out }}-q_{\text {in }}\right) / \Delta h_{\text {Rabi }}
$$




\subsection{Specific yield at a $2 \mathrm{D}$ scale}

250

251

252

253

254

255

256

257

258

259

260

261

262

263

264

265

266

267

268

269

270

271

272

Maréchal et al. (2006) and Dewandel et al. (2010) estimated the specific yield $\left(S_{\mathrm{y}}\right)$ values at the watershed scale of this area and found a global value of $1.4 \pm 0.3 \%$. At watershed scale, horizontal inflow $\left(q_{\text {in }}\right)$ and outflow $\left(q_{\text {out }}\right)$ are low $(<1 \mathrm{~mm} / \mathrm{y})$ and thus their balance can be neglected $\left(q_{\text {in }}-q_{\text {out }}=0\right)$. However, for small cells $($ e.g. $100 \mathrm{~m} \times 100 \mathrm{~m})$, their balance cannot be neglected as the radius of influence of a given pumping well will be larger than the size of the cell. Therefore, for this example, assuming a nil $q_{\text {in }}-q_{\text {out }}$ will induce an overestimation of $S_{\mathrm{y}}$ when using Eq. 4. Conversely, if the cell size is larger than the radius of influence of the pumping, or a group of pumping wells, the pumped volume will be abstracted from this large cell, and thus the $S_{\mathrm{y}}$ estimate will be correct. The approach proposed in Dewandel et al. (2012) is similar to a coarse-graining method, which means that the system is observed with a decreasing number of cells whose size is increasing. The principle of this method consists in investigating how a groundwater budget may depend on cell size. Since the aquifer is heavily pumped for irrigation, the main component of water flow ( $Q$ and IRF) is vertical, except near the pumping wells where horizontal flow is not negligible (i.e. $q_{\text {in }}$ and $q_{\text {out }}$ ). Thus, horizontal flow may occur in a small cell, but should disappear or be counterbalanced as the cell size increases toward a particular threshold, which depends upon the typical spacing between pumping wells (or group of pumping wells), as well as on local aquifer properties. As $Q$-IRF and $\Delta h$ are known and ' $q_{\text {in }}-q_{\text {out }}$ ' (horizontal flow) is unknown, the aim of the method is to optimize the cell size for which ' $q_{\text {in }}-q_{\text {out }}$ ' is negligible compared to vertical flow (i.e. $Q$ and IRF), by making a cluster of groundwater-budget computations using increasing cell sizes. This threshold determines the minimum cell size from which a 2D specific yield field (map) can be computed. For the study area, Dewandel et al. (2012) found that a realistic $S_{\mathrm{y}}$ map can be computed from a cell-size higher than $520 \mathrm{~m} \times 520 \mathrm{~m}$. Accordingly, the aquifer can reasonably be considered as a set of closed systems above this threshold cell size. They also 
compared $S_{\mathrm{y}}$ values from computations on $650 \mathrm{~m} \times 650 \mathrm{~m}$ cells with those from $800 \mathrm{~m} \times$ $800 \mathrm{~m}$ and $1040 \mathrm{~m} \times 1040 \mathrm{~m}$ cell sizes. Except for a few cells, the difference was very small and still in the range of standard deviations, which shows that the hypothesis of negligible $q_{\text {in }}-q_{\text {out }}$ is valid for large cell sizes. These studies showed that size of the cell mainly depends upon the aquifer properties and also on the spacing of the pumping wells. As both properties do not change significantly during the period of analysis. This size is kept applicable too in this study. Based on this result, a cell size of $685 \mathrm{~m} \times 685 \mathrm{~m}$ was chosen (number of cells in the model: 113). Assuming a nil ' $q_{\text {in }}-q_{\text {out }}$ ' in Eq. 4, leads to:

$$
S_{\mathrm{y}}=\left(Q_{\mathrm{Rabi}}-\mathrm{IRF}_{\mathrm{Rabi}}\right) / \Delta h_{\mathrm{Rabi}}
$$

All computations were performed on $685 \mathrm{~m} \times 685 \mathrm{~m}$ cell size, allowing for computing of $2 \mathrm{D}$ $S_{\mathrm{y}}$ maps over the five non-monsoon seasons. However, maps are valid for the zone where the water table fluctuates only.

\subsection{Specific yield at 3D scale}

Dewandel et al. (2017) proposed a method for regionalizing specific yield in three dimensions (3D) from the 2D maps and geological information. Indeed, in the weathering profile, the water table fluctuates not only locally within the saprolite layer, or at the top of the fractured layer, but also deeper. Therefore, the previously estimated $S_{\mathrm{y}}$ values for each cell are also a representative at a particular depth within the weathering profile. For estimating the 3D specific yield field, the system was sliced horizontally along the saprolite and fractured-layer interface (Dewandel et al., 2006, for the mapping of this interface). Depth intervals were chosen every $5 \mathrm{~m}$ in the fractured layer except for the last layer, whose thickness is defined according to bedrock depth. As the $S_{\mathrm{y}}$ values of each depth interval do not cover the entire watershed, the data were subjected to statistical and variogram analyses, and kriging was used to produce the $S_{\mathrm{y}}$ field for each depth interval. After that, the 
aggregation of all depth intervals produces the 3D $S_{\mathrm{y}}$ field (maps of each layer are shown in Figure-S2 of the electronic supplementary material (ESM)).

\subsection{Recharge}

Once the 3D $S_{\mathrm{y}}$ model is ready, the recharge can be computed using the groundwater-budget component during the monsoon season and the following equation:

$$
R=Q_{\text {kharif }}-\mathrm{IRF}_{\text {kharif }}+\left(S_{\mathrm{y}_{-} \text {model }} \times \Delta h_{\text {kharif }}\right)
$$

where $S_{\mathrm{y}_{-} \text {model }}$ is the specific yield value from the 3D $S_{\mathrm{y}}$ model $(685 \mathrm{~m}$ x $685 \mathrm{~m}$ cell size) according to the zone where the water level fluctuates (i.e. the elevation where $\Delta h_{\text {kharif }}$ occurs). Nil recharge was assigned to dry cells $(R=0)$, but these are very few and at the rim of the area. As this method considers the horizontal and vertical variations of $S_{\mathrm{y}}$ in the aquifer, the method is more accurate than the classic WTF method, which usually assumes a constant $S_{\mathrm{y}}$ value for the entire aquifer thickness.

A recharge model then was developed based on the five years of data. A linear relationship between recharge and annual rainfall (Recharge $=a \times$ Rainfall $+b$; where $a$ and $b$ are constant) was established at watershed scale and linear to moderately linear at cell scale. This model then was applied to rainfall values for the modelling of recharge over a longer period.

\subsection{Computation of water levels}

After computation of both 3D $S_{\mathrm{y}}$ and the recharge model, water levels were computed for each cell at seasonal time steps from October 2011 to May 2016, to reproduce the 10 water table maps. The May-2011 water map was used as a starting point for the generation of water level maps for the rest of the period. The computed water level $h_{t+1}$, at time $t+1$, i.e. that of the next season, can be written as follows (Dewandel et al., 2010): 


$$
h_{t+1}=h_{t}+\frac{1}{S_{\mathrm{y}_{i+1}}}\left[\Delta S_{t+1}-\sum_{i=1}^{n}\left(Y_{(i+1)}-h_{t}\right) S_{\mathrm{y}_{i}}+\left(Y_{(i+1)}-Y_{i}\right) S_{\mathrm{y}_{i}}\right]
$$

and for $\Delta S<0$ :

$$
h_{t+1}=h_{t}+\frac{1}{S_{\mathrm{y}_{i-1}}}\left[\Delta S_{t+1}-\sum_{i=1}^{n}\left(\mathrm{~h}_{t}-Y_{i}\right) S_{\mathrm{y}_{i}}+\left(Y_{i}-Y_{(i-1)}\right) S_{\mathrm{y}_{i}}\right]
$$

325

326

327

329

330

331

where $h_{t}$ is the water level at time $t$; $S_{\mathrm{y} i}$ the specific yield of discretized layer $i$ deduced from the 3D model; $\Delta S_{t+1}$ the storage variation at $t+1$; and $Y_{i}$ the bottom of the discretized layer $i$. Computed levels were compared with measured levels for evaluating the robustness of the model from 2011 to 2016.

\section{RESULTS}

\subsection{Specific yield $\left(S_{\mathrm{y}}\right)$}

\subsubsection{The 2D approach}

Figure $\mathrm{S} 1$ of the ESM presents the mean value of all five non-monsoon (dry) seasons for $Q$ IRF and $\Delta h$ on $685 \mathrm{~m} \times 685 \mathrm{~m}$ cell size. Mean $\Delta h$ is $3.8 \mathrm{~m}$ and mean $Q$-IRF is $52 \mathrm{~mm}$ at watershed scale for these non-monsoon (dry) seasons. Equation 5 was used for the estimation of $S_{\mathrm{y}}$ for each non-monsoon season at cell scale for the zones where the water table fluctuates. $S_{\mathrm{y}}$ values range within the watershed between 0.003 to 0.05 , with an average of 0.014. The average value of $S_{\mathrm{y}}$ for Nov 2011-May 2012 is $0.012,0.012$ for Nov 2012-May 2013, 0.018 for Nov 2013-May 2014, 0.014 for Nov 2014-May 2015, and 0.014 for Nov 2015-May 2016.

Each value corresponds to a different depth location within the weathering profile depending on the water-level fluctuations. These values agree with earlier results from this 
area $\left(S_{\mathrm{y}}: 0.014\right.$, Maréchal et al., 2006 and Dewandel et al., 2010; $S_{\mathrm{y}} 0.008$ to 0.028 , average 0.015, Dewandel et al., 2012). A closely similar value of $S_{\mathrm{y}}(0.017)$ was recorded by Chinnasamy et al. (2018) in the Dharta region of Rajasthan, India, which is underlain by granitic and quartzitic aquifers.

\subsubsection{The 3D approach}

According to the described methodology, each $S_{\mathrm{y}}$ value of the five 2-D $S_{\mathrm{y}}$ maps was associated with its location in the weathering profile. The five 2-D $S_{\mathrm{y}}$ maps show that about $20 \%$ of the $S_{\mathrm{y}}$ values fall in the saprolite layer and about $80 \%$ in the fractured layer because water level barely rises to the saprolite layer. All levels were referenced according to the interface between the saprolite and fractured layer. As the number of $S_{\mathrm{y}}$ values is low in the saprolite layer, only one layer has been considered for it $(-10-0 \mathrm{~m}$; depth 0 is the saprolite/fractured interface). For the fractured layer, the system was sliced into four depth intervals, which are 0-5 m (85 data points out of 113 cells), 5-10 m (56 data points out of 113 cells), $10-15 \mathrm{~m}$ (43 data points out of 113 cells) and >15 m (13 data points out of 113 cells). The $S_{\mathrm{y}}$ values in saprolite and the first three depth intervals of the fractured layer (0-5 to 10$15 \mathrm{~m}$ ) show normal to near normal distributions with average $S_{\mathrm{y}}$ values of: $0.019 \pm 0.008$ for saprolite, $0.0147 \pm 0.008$ for the $0-5 \mathrm{~m}$ depth interval of the fractured layer, $0.0140 \pm 0.007$ for the 5-10 m depth interval and $0.0108 \pm 0.069$ for the $10-15 \mathrm{~m}$ depth interval of the fractured layer (Fig. 4). For the deepest fractured layer $\left(>15 \mathrm{~m}\right.$ ), the $S_{\mathrm{y}}$ value does not follow the normal distribution, probably because of the very low number (13) of data points, and these do not allow a variographic analysis.

Except for the last depth-interval of the fractured layer, a variographic analysis was made on each data set for evaluating the spatial dependency parameter prior to data interpolation. This analysis shows nugget/sill ratios varying from 0 to 0.1 for the $S_{\mathrm{y}}$ values of 
the saprolite layer and of the first three depth intervals of the fractured layer. These ratios give information on the spatial dependency of the parameter (Ahmadi and Sedghamiz, 2007). If the ratio is below 0.25 , it suggests that the variable has a strong spatial dependency and if it ranges from 0.25 to 0.75 it can be said that dependency is moderate to weak. In this case, $S_{\mathrm{y}}$ thus has a strong spatial dependency for saprolite and until $15 \mathrm{~m}$ depth in the fractured layer.

Maps for the depth intervals -10-0, 0-5, 5-10 and 10-15 were established using kriging techniques with respective variograms (see Figure S2 of the ESM). Mean $S_{\mathrm{y}}$ values were $0.0185 \pm 0.0058$ for the saprolite layer (mean depth $-3.2 \pm 2.56 \mathrm{~m}$ ), $0.015 \pm 0.007$ for the $0-5 \mathrm{~m}$ (mean depth $2.7 \pm 1.37 \mathrm{~m}$ ) interval, $0.013 \pm 0.0056$ for the $5-10 \mathrm{~m}$ (mean depth: $7.1 \pm 1.48 \mathrm{~m}$ ) interval, and $0.010 \pm 0.004$ for the $10-15 \mathrm{~m}$ (mean depth: $12.3 \pm 1.26 \mathrm{~m}$ ) interval of the fractured layer (Fig. 5). For the deepest interval of the fractured layer $>15 \mathrm{~m}$ (mean depth $17.5 \pm 1.9 \mathrm{~m}$ ), the mean $S_{\mathrm{y}}$ value was $0.005 \pm 0.0019$. The $S_{\mathrm{y}}$ value of the last depth interval of the fractured layer $(>15 \mathrm{~m})$ is taken to be an average of the $S_{\mathrm{y}}(0.010)$ of depth interval 10$15 \mathrm{~m}$ and that of bedrock $\left(S_{\mathrm{y}}=0\right)$. Durand et al., (2017) also found that the saprolite layer is about 2.5 times more capacitive than the fractured layer (Saprolite layer $S_{\mathrm{y}}=\sim 10 \%$ against fractured layer $\left.S_{\mathrm{y}}=\sim 2 \%\right)$.

\subsection{Recharge}

Based on the 3-D $S_{\mathrm{y}}$ model, a spatial seasonal recharge model was computed using Equation 6. The average recharge (from 2011 to 2015) was $28 \mathrm{~mm}$ for Jun 2011-Oct 2011, $60 \mathrm{~mm}$ for Jun 2012-Oct 2012, $199 \mathrm{~mm}$ for Jun 2013-Oct 2013, $16 \mathrm{~mm}$ for Jun 2014-Oct 2014 and $58 \mathrm{~mm}$ for Jun 2015-Oct 2015, with standard deviations due to its spatial variation of $20 \mathrm{~mm}, 56 \mathrm{~mm}, 137 \mathrm{~mm}, 27 \mathrm{~mm}$ and $54 \mathrm{~mm}$, respectively.

Based on the estimated recharge and annual rainfall of the area, a linear relationship (Fig. 6) was defined at the watershed scale. This relationship is consistent with earlier studies 
carried out in the area at watershed scale between 2001 and 2004, for a similar range of annual rainfall (Maréchal et al., 2006; Dewandel et al., 2010). The relationship found is Recharge $=0.31 \times$ Rain -152 , with a regression coefficient $\left(R^{2}\right)$ of 0.93 . It shows, at the watershed scale, that a minimum of about $490 \mathrm{~mm}$ of rainfall is necessary to start recharge.

Watershed-scale recharge maps (Fig. 7) present a large spatial variability and a very similar pattern in spite of the large range of annual recharge values, which cannot be explained by rainfall variability. Indeed, it was shown that the area has no significant rainfall variability at a seasonal scale (Condappa et al., 2005). This point will be discussed later.

At the cell scale, Figure 8 (histogram of $R^{2}$, slope and intercept of rainfall/recharge linear relationship) shows that the recharge estimates also correlate well with annual rainfall at watershed scale ( $72 \%$ with $R^{2} \geq 0.75$, and $83 \%$ with $\left.R^{2} \geq 0.50\right)$. The slope of these linear relationships ranges from 0.08 to 0.78 (average 0.31 ) and intercepts range between 10 and 480 (average 152.7$)$. Some cells $(\sim 16 \%$ of the area) show a poor correlation because of the lack of data, as the cells were dry during some seasons. The relatively good correlation at a watershed scale between average annual rainfall and estimated recharge suggests that the computed linear relationships at cell scale can be used for estimating future spatial recharge from the rainfall model.

\subsection{Model validation}

Water levels were computed using Equations (7) and (8) at watershed scale and then compared with existing water maps. Figure 9 shows computed vs. observed water-level data, with a strong correlation coefficient for each of the ten seasonal maps $\left(R^{2}>0.97\right)$. Absolute residual means (ARM) varied between 0.006 and $4.04 \mathrm{~m}$ (average $1.17 \mathrm{~m}$ ), and root mean square error (RMSE) values were between 0.3 and $2.3 \mathrm{~m}$ (average $1.8 \mathrm{~m}$ ). This result demonstrates the robustness of the methods used for estimating the hydrogeological 
parameters $\left(S_{\mathrm{y}}\right.$-porosity field, recharge model) and thus the robustness of the model. A spatial

ARM map (see Figures S3 of the ESM) shows that, except for a few zones with ARM >3 m ( $16 \%$ of the area), the ARM is below $2 \mathrm{~m}$ with an average of $1.17 \mathrm{~m}$. This result is very reasonable compared to the mean $\Delta \mathrm{h}$ during the measuring period $(3.8 \mathrm{~m})$. This also shows the robustness of the model.

\subsection{Projection of future water levels}

Once the model was calibrated and validated, projections were generated of future water levels that used different climatic and groundwater-management scenarios. The model was linked with regional downscaled rainfall data (Vigaud et al., 2013). This downscaled rainfall was calibrated for 1971-1999 and time-slice projections were generated from 2020 to 2039 . However, such downscaled rainfall projections were made at a $50 \mathrm{~m} \times 50 \mathrm{~km}$ scale, quite different from local rainfall observations for the Maheshwaram area, itself only $53 \mathrm{~km}^{2}$, even if downscaled rainfall models were bias-corrected. To evaluate the impact of the error introduced by downscaling, water levels were computed with both observed rainfall and downscaled rainfall from 1990 to 1995 at watershed scale (See Figure S4 of the ESM). The average difference of water levels was $\pm 2.6 \mathrm{~m}$, suggesting that future scenarios not exceeding this range can be considered as not significant.

For testing the impact of different management strategies on groundwater resources, a climate impact scenario and a pumping impact scenario were generated. In the climate scenario (Fig. 10, Scenarios 1 and 3), the study considered the impact of climate change and constant groundwater abstraction on future (2020-2039) water levels. Scenario 1 shows the impact of climate change on groundwater level without changing groundwater abstraction patterns in the area (constant for all seasons). In this scenario, the consecutive bad monsoons 
should lead to a strong depletion of water levels around 2025, after which the water level should rise because of the higher frequency of good (above the average rainfall per year) to average forecasted monsoons. Scenarios 2 and 3 are sensitivity tests on water levels based on a $10 \%$ decrease (scenario 2) and a $10 \%$ increase (scenario 3 ) of the projected rainfall of scenario 1 . The resulting water-level trends are almost similar to those of scenario 1 , but in scenario 2 depletion will occur one or two years earlier compared to scenario 1 . Scenario 4 shows the forecast water levels when considering groundwater abstraction according to Fig. 3a and downscaled rainfall model. In this case, the water-level trend is similar to the other scenarios, but higher groundwater abstraction will cause more depletion and vice versa. Scenario 4 presents, according to author's knowledge, a realistic condition in terms of groundwater pumping variation because here it was observed that the groundwater abstraction pattern is varying based on the availability of groundwater. Farmers adapt to the conditions and increase/decrease the land-use area according to groundwater resources.

\section{DISCUSSION}

\section{$452 \quad 5.1$ Specific yield $\left(S_{\mathbf{y}}\right)$}

453 Comparison between $S_{\mathrm{y}}$ maps (see Figure-S2 of the ESM) and the geology of the area (Fig. 1b) does not show any clear correlation. This indicates, as mentioned earlier (Dewandel et al., 2012, 2017) that lateral $S_{\mathrm{y}}$ variations within the same geology (e.g. a granite) and weathering profile are more important than the variability in $S_{\mathrm{y}}$ between rocks of similar mineralogy (e.g. various granites, gneisses) exposed to the same weathering processes.

Based on the 3D $S_{\mathrm{y}}$ model, mean $S_{\mathrm{y}}$ values from each depth interval were computed (Fig. 5). This shows that the higher $S_{\mathrm{y}}$ value occurs in the saprolite layer, with a value of $1.8 \%( \pm 0.0058)$, which is consistent with values commonly found in the literature (Bodelle and Margat 1980; Compaore et al., 1997, Wyns et al., 2004; Dewandel et al 2017; Durand et 
al., 2017). Deeper down, in the fractured layer, $S_{\mathrm{y}}$ values gently decrease, from $1.5 \%$ at the top to $0.5 \%$ in the $15-20 \mathrm{~m}$ depth interval. A similar result was found in Dewandel et al. (2017), in other granitic aquifers of India. its computation requires a lot of data. However, this exercise was performed in previous work (Dewandel et al., 2012) on the same aquifer in 2-D where the maximum expected uncertainty was estimated as 0.014 on average. Figure 5 ( $S_{\mathrm{y}}$ vs depth) shows that $S_{\mathrm{y}}$ values and depth variation is in agreement with previous studies on different terrains of granitic aquifer (Dewandel et al., 2018), and Figure 9 (Calculated vs Observed water level elevation for each season) demonstrates that computed water level elevations (which requires $S_{\mathrm{y}}$ values) agree with observed water level elevations. Thus, even if one cannot produce a clear estimate of error in $S_{\mathrm{y}}$, outcomes are coherent and suggest low error values or a reasonable error. In addition, $S_{\mathrm{y}}$ values estimated in the fractured layer (0.008 mean) agree with $S_{\mathrm{y}}$ deduced from the pumping test performed in the area (0.0063; Marechal et al., 2004).

Comparing $\mathrm{S}_{\mathrm{y}}$ values with hydraulic conductivity in the same watershed shows (Dewandel et al., 2012) that an area of low conductivity more or less coincides with low $S_{y}$ values and vice versa (Dewandel et al., 2012). This coincidence, which was also noted by earlier studies (e.g. Illman and Tartakovsky, 2006) is probably not an artefact because, in fractured media, $\mathrm{S}_{\mathrm{y}}$ primarily depends on the density of productive fractures as well as on low-permeability, but porous associated weathering products.

In the fractured zone of the weathering profile, hydraulic conductivity and specific yield primarily depend on the degree of weathering and thus on fracture density, which itself decreases with depth (Acworth, 1987; Wyns et al., 1999; Maréchal et al., 2004; Dewandel et al., 2006, 2010). The fracture density and hydraulic conductivity of conductive fracture zones 
$486\left(K_{\mathrm{cfz}}\right)$ were investigated with flow-meter measurements in 19 wells (Dewandel et al.,2006),

487 which identified the depth location of hydraulically conductive fractures (Fig. 11).The

488

489

490

491

492

493

494

495

496

497

498

499

500

501

502

503

504

505

506

507

508 authors showed that $K_{\mathrm{cfz}}$ does not depend on depth (Fig. 11d), but that equivalent hydraulic conductivity ( $K_{\text {eq }}$, the product of $K_{\text {cfz }}$ with fracture density) decreases with depth because of a decrease in fracture density (Fig. 11a and b).

Comparison between $S_{\mathrm{y}}$ (Fig. 5) and fracture density (df; Fig. 11 a) in the fractured layer shows a clear linear relationship $\left(S_{\mathrm{y}}=0.063 \times \mathrm{df}+0.0004\right.$; see Figure $\mathrm{S} 5$ of the ESM $)$.

Considering a basic system composed of planar fractures, it is easy to show that the specific yield $\left(S_{\mathrm{y}}\right)$ can be expressed as a function of aperture $\left(e_{\mathrm{f}}\right)$, and fracture density $\left(S_{\mathrm{y}}=e_{\mathrm{f}} \times \mathrm{df}\right)$.

This means that, on average, fracture aperture $\left(e_{\mathrm{f}}\right)$ is about $6 \mathrm{~cm}$, which seems to be a realistic value even if it is a probable underestimation because the porous weathering product around fractures is not considered. This fairly good relationship also shows that $S_{\mathrm{y}}$ decreases with depth because of the decrease in fracture density but not because of a decrease in hydraulic conductivity of individual fracture zones $\left(K_{\mathrm{cfz}}\right)$.

\subsection{Recharge}

Estimated values of recharge at the watershed scale agree with previous results (Fig. 6; Maréchal et al., 2006; Dewandel et al., 2010). The found linear relationship at watershed scale is also consistent with other studies carried out in granitic areas of South India, which use tritium as recharge tracer (Sukhija et al., 1996; Rangarajan and Athavale, 2000). However, such a local approach, gives only the minimum recharge ('direct' recharge) and does not take account of both 'indirect' recharge, the percolation through rivers and tank beds, and 'localized' recharge through local geological or topographic variations (Lerner et al., 1990; Maréchal et al., 2006). This is why values from the model are higher. 

within a soil type. Johnston (1987) found varying recharge rate associated with a discontinuity in the regolith. Welling and Cooper (1983) discussed the recharge variability related to different geology and climate. Montety et al., (2019) described the understanding of recharge processes through long term monitoring of dissolved gases in a shallow crystalline aquifer.

The spatial distribution of recharge in the Maheshwaram watershed is characterized by a large spatial variability (Fig. 7), but shows a very interesting similar pattern from one year to another, despite of its important mean annual variation (from 16 to $199 \mathrm{~mm} / \mathrm{y}$ ). Recharge is higher in the western part than in the eastern part of the watershed and tends to be higher near streams.

The spatial variability of the recharge can be due to rainfall, land use, soil spatial variability, and/or spatial variability of geomorphology and geology, particularly the geometry of the weathering profile (Harte and Winter, 1996, Nolan et al., 2007, Prasmma et al., 2008). As mentioned earlier, the spatial variability of rainfall alone cannot explain the spatial variability of recharge (Condappa et al., 2005). The recharge maps suggest, as a first point, that recharge is higher in valley areas (Fig. 7), whereas other parameters like soil, geology and weathering-profile thickness seem to be of secondary importance. A Box and

529 Whisker plot (Fig. 12b) shows that more recharge occurs in Alfisol soil type followed by 530 Alfisol+Entisol (both are present within a same cell of the model), 531 Alfisol+Entisol+Inceptisol, Entisol and Inceptisol. Mean particle-size fractions for the watershed soils show that clay, silt and sand percentages are 19\%, 12\% and 69\% in Alfisol, and 22\%, 21\% and 56\% in Entisol, respectively (Condappa et al., 2006). The higher mean 
recharge in Alfisol as compared to Entisol in the watershed is probably because the soil profile of Entisol contains more silt than that of Alfisol, offering a soil, less appropriated to percolation and thus recharge. It is not clear why Inceptisols have a lower recharge; it may be due to their location 'far' from valleys and their silty fraction (>40\%; USDA, 1999). Entisols are more dominant in streams but this does not seem to favour recharge. However, at this stage one cannot be certain that recharge is higher because of the presence of Alfisol, or because of a higher recharge in valley areas where surficial fluxes concentrate. So-called 'tanks' (artificial ponds, Entisol) also show a high mean recharge, showing that such structures contribute locally to favour recharge (Boisson et al., 2014). Moreover, a recent study on artificial recharge processes in fractured crystalline environments highlighted that the lateral transmission of recharge reaching the aquifer is ensured mainly by the saprolite/fractured interface (Nicolas et al., 2019).

\subsection{Projection of future water levels}

\subsubsection{Impact of climate change}

The model allows for groundwater-level forecast maps for different scenarios that determine which areas will be more exposed to drought conditions (Scenarios 1 to 3; Fig.13). It shows that severe water-level lowering should occur in the next decade in spite of an unchanged pumping scenario. During the three projected (2024-2026) consecutive bad monsoons (less than average rainfall per year), almost all of the watershed (>93\%) will be exposed to drought (Fig. 13a). If the projected downscaled rainfall is $10 \%$ more (Scenario 3; Fig. 13c), about $33 \%$ of the aquifer will be still saturated, but mainly where the aquifer is the thickest. However, with an increase in the frequency of good monsoons (above the average rainfall per year) and a lower frequency of bad monsoons in the second decade (>2030), all of the aquifer 
should be saturated with water (Fig. 13d), thus, according to the proposed scenario, alleviating the problem of drought in this area.

These groundwater level simulations suggest that the agricultural economy would potentially suffer more during the next decade because of higher frequency of consecutive bad monsoons, than during the second decade because of the decrease in the frequency of bad monsoons.

\subsubsection{Changing pumping rates}

The forecasted water-table elevations for June-2025 (Scenario 4; Fig. 10) present similar information in the maps of Figs. 13a, b and c. Even though the predictive rainfall models forecast an increase in rainfall for the decade 2030-2039, the tested scenarios 1 to 4 show that the area should be exposed to severe groundwater depletion during 2020-2030 because of the possible occurrence of two or three consecutive low monsoons. Therefore, in the short term, groundwater-resource management measures are needed to limit the negative climatic impact on the farming economy. This could be done through maximizing surface-water usage (direct use from tanks and favouring the cultivation of rain-fed crops; Perrin et al., 2012), through preserving and managing the artificial recharge structures (i.e., tanks; Boisson et al., 2014), and through the preservation of groundwater reserves to be used as a supplementary resource during dry years. This would, however, require strict demand-management measures (less pumping during dry years) and community-based water resource management.

\section{6. CONCLUSIONS}

577 The developed 2-D spatial scale hydrogeological model is based on groundwater-budget and water-table-fluctuation (WTF) methods, and on an upscaling method for regionalizing aquifer parameters (3D $S_{\mathrm{y}}$ model and recharge). This procedure is more accurate than the classic 
model estimates the 3D distribution of $S_{\mathbf{y}}$, which allows computing reliable 2D recharge values as well as projections of future groundwater levels. Model results, particularly 3-D $S_{\mathrm{y}}$ and 2-D recharge, can be used and/or to complement numerical models such as MODFLOW and MARHE (Thiéry, 1990 and 2018). However, these last models require - among othersa hydraulic-conductivity field, which is a topic of large uncertainty in crystalline aquifers, but not necessary in this model.

The cell size from which computations can be performed depends upon the location of pumping wells and the aquifer properties. This cell size, for which horizontal in- and outflow from the aquifer (or their difference) can be neglected compared to vertical flux (i.e., pumping and recharge), must be known before using the model (Dewandel et al, 2012, 2017). Here, the computations performed on the Maheshwaram $53 \mathrm{~km}^{2}$ watershed where done on a grid with $685 \times 685 \mathrm{~m}$ cell size according to previous results.

The model is applicable in unconfined aquifers and can be used in other geological settings, like basaltic or alluvial aquifers, but aquifers should be significantly pumped to allow a relevant evaluation of the minimum cell size to be used for computations and thus proper estimates of aquifer parameters ( $S_{\mathrm{y}}$ and recharge). Also, the model requires a good knowledge of water-table conditions, aquifer geometry and groundwater abstraction.

The ability to produce spatial recharge maps constrained by aquifer properties bring a new insight to improve groundwater management policies and help the decision makers. They may suggest the right areas to farmers for growing high water-consuming agricultural crops, or for identifying the areas vulnerable to water scarcity due to over-pumping and low recharge, or for preserving or favouring aquifer recharge. For the Maheshwaram area, the resulting maps show that the western part of the watershed receives more recharge than the eastern part, suggesting that these two areas cannot support the same rate of pumping and 
should be managed differently. The resulting recharge maps also reveal a strong spatial variability, with similar patterns despite the amount of annual recharge. This variability is still not well understood and may have many causes among soil properties, topography etc. This has very recently been discussed in a PhD thesis (Nicolas, 2019) using an unsaturated flow model. This is foreseen to be the topic of another paper. simulations. The results show severe aquifer depletion for the next decade, but stable water levels after 2030, because of a lower frequency of bad monsoons. These results show that the government and famers should start to implement schemes or programs in order to prevent this depletion of the water level. Alternatives like crop pattern adaptations or stronger control on borewell/groundwater extraction etc. should be considered for the near future.

Even if the model has been successfully tested on a small watershed, it is expected to be tested and used in a larger area $\left(>1000 \mathrm{~km}^{2}\right)$, at a scale more adapted to groundwater management and policies. Here, the model was tested on a small watershed because of the availability of significant data (e.g. detailed piezometric maps, groundwater withdrawn from borewells etc. and published works since 2000). This allowed for the testing of the sensitivity of the tool to this large data set. It is believed that such a tool could be used on a larger scale if appropriate data are available. For instance, 3-D estimates of effective porosity have been carried out on such large scale on different granite terrain of India (area $>700 \mathrm{~km}^{2}$ Dewandel et al., 2017). This study is the beginning, and further refinements will be required on spatial and temporal scales so that it will become a tool for unique decision making. For example, the variation of groundwater pumping could be refined by using an almost real-time estimation of the irrigated areas from satellite data (Ferrant et al., 2017). 
The authors are very grateful to CEFIPRA New Delhi, DST India, the French Embassy India, CSIR-NGRI and BRGM, Montpellier. The present research was carried out under a RamanCharpak fellowship supported by DST India and the French Embassy India. The authors are very thankful to the three anonymous reviewers and an Editor for their fruitful comments and suggestions, which has improved the quality of the manuscript. The first author wishes to thank the Director-of NGRI for the permission for publication. We thank Dr. H.M. Kluijver for revising the English text of this paper and Sue Duncan for the technical advice.

\section{REFERENCES}

Acworth, R.I. (1987). The development of crystalline basement aquifers in a tropical environment. Quarterly Journal of Engineering Geology and Hydrogeology, 20, 265-272.

Ahmadi, S.H. and Sedghamiz, A. (2007) Geostatistical Analysis of Spatial and Temporal Variations of Groundwater Level. Environmental Monitoring and Assessment, 129, 277294.

Alcalá, F. J., \& Custodio, E. (2014). Spatial average aquifer recharge through atmospheric chloride mass balance and its uncertainty in continental Spain. Hydrological Processes, 28(2), 218-236.

Allison, G. B. (1988). A review of some of the physical, chemical and isotopic techniques available for estimating groundwater recharge. In Estimation of natural groundwater recharge (pp. 49-72). Springer, Dordrecht.

Allison, G. B., \& Hughes, M. W. (1978). The use of environmental chloride and tritium to estimate total recharge to an unconfined aquifer. Soil Research, 16(2), 181-195.

Bodelle, J. \& Margat, J. (1980). L'eau Souterraine en France (Underground water in France). Masson.

Boisson, A., Baisset, M., Alazard, M., Perrin, J., Villesseche, D., Dewandel, B. \& Ahmed, S. (2014). Comparison of surface and groundwater balance approaches in the evaluation of managed aquifer recharge structures: Case of a percolation tank in a crystalline aquifer in India. Journal of Hydrology, 519, 1620-1633.

Chilton, P.J. \& Foster, S.S.D. (1995). Hydrogeological characterization and water-supply potential of basement aquifers in tropical Africa. Hydrogeology Journal, 3(1), 36-49. 
Chinnasamy, P., Maheshwari, B., Dillon, P., Purohit, R., Dashora, Y., Soni, P. \& Dashora, R. (2018). Estimation of specific yield using water table fluctuations and cropped area in a hardrock aquifer system of Rajasthan, India. Agricultural Water Management, 202, 146155.

Compaore, G., Lachassagne, P., Pointet, T., Travi, Y., 1997. Évaluation du stock d'eau des altérites. Expérimentation sur le site granitique de Sanon (Burkina-Faso) (Assessment of the water supply of alterites. Experimentation on the granitic site of Sanon (Burkina-Faso)). In: Rabat IASH Conference, IASH, vol. 241, pp. 37-46.

Cook, P. G., Walker, G. R., \& Jolly, I. D. (1989). Spatial variability of groundwater recharge in a semiarid region. Journal of hydrology, 111(1-4), 195-212.

Courtois, N., Lachassagne, P., Wyns, R., Blanchin, R., Bougaïré, F.D., Somé, S. \& Tapsoba, A. (2010). Large- Scale Mapping of Hard- Rock Aquifer Properties Applied to Burkina Faso. Groundwater, 48, 269-283.

Courtois, N., Lachassagne, P., Wyns, R., Blanchin, R., Some, S., Tapsoba, A. \& Bougaïre, F.D. (2008). Experimental GIS hydrogeological mapping of hard-rock aquifers in Burkina Faso, to help for groundwater management and planning. Poster at International Conference 'Groundwater and Climate in Africa', June 24-28, Kampala, Uganda.

De Condappa, D. (2005). Study of the spatialized water flow processes of the vadose zone of hard-rock aquifers. Implementation for the evaluation of the recharge at the watershed scale, Maheswharam watershed, Andhra Pradesh, India. PhD Thesis, University of Grenoble, France.

De Condappa, D., Galle. S., Dewandel. B., \& Haverkamp, R. (2006). Bimodal zone of the soil textural triangle: Common in tropical and subtropical regions. Soil Physics, SSSAJ: Volume 72: Number 1. doi:10.2136/sssaj2006.0343

De Montety, V., Aquilina, L., Labasque, T., Chatton, E., Fovet, O., Ruiz, L., Fourre, E., De Dreuzy, J. R. (2018). Recharge processes and vertical transfer investigated through long-term monitoring of dissolved gases in shallow groundwater. Journal of Hydrology, 560, 275-288.

Dewandel, B., Caballero, Y., Perrin, J., Boisson, A., Dazin, F., Ferrant, S. \& Maréchal, J.C. (2017). A methodology for regionalizing 3- D specific yield at the watershed scale in crystalline aquifers. Hydrological Processes, 31, 2277-2295.

Dewandel, B., Maréchal, J.C., Bour, O., Ladouche, B., Ahmed, S., Chandra, S., \& Pauwels, H. (2012). Upscaling and regionalizing hydraulic conductivity and specific yield at the watershed scale in deeply weathered crystalline aquifers. Journal of Hydrology, 416, 83-97.

Dewandel, B., Perrin, J., Ahmed, S., Aulong, S., Hrkal, Z., Lachassagne, P., \& Massuel, S. (2010). Development of a tool for managing groundwater resources in semi- arid hard rock regions: application to a rural watershed in South India. Hydrological Processes, 24, 27842797. 
Dewandel, B., Gandolfi, J. M., De Condappa, D. \& Ahmed, S. (2008). An efficient methodology for estimating irrigation return flow coefficients of irrigated crops at watershed and seasonal scale. Hydrological Processes, 22, 1700-1712.

Dewandel, B., Lachassagne, P., Wyns, R., Maréchal, J.C. \& Krishnamurthy, N. S. (2006). A generalized 3-D geological and hydrogeological conceptual model of granite aquifers controlled by single or multiphase weathering. Journal of Hydrology, 330, 260-284.

Durand, V., Léonardi, V., De Marsily, G. \& Lachassagne, P. (2017). Quantification of the specific yield in a two-layer hard-rock aquifer model. Journal of Hydrology, 551, 328-339.

Ferrant, S., Selles, A., Le Page, M., Herrault, P.A., Pelletier, C., Al-Bitar, A. \& Dewandel, B. (2017). Detection of Irrigated Crops from Sentinel-1 and Sentinel-2 Data to Estimate Seasonal Groundwater Use in South India. Remote Sensing, 9, 1119.

Harte, P.T., Winter, T.C., 1996. Factors affecting recharge to crystalline rock in the MirrorLakeArea,Grafton County,NewHampshire.In:U.S.G.S. ToxicSubstances Hydrology Program - Proceedings of the Technical Meeting, Colorado Springs, Colorado, September 20-24, 1993, Water-Resources Investigations Report 944015.

Ilman, W.E. \& Tartakovsky, D.M., 2006. Asymptotic analysis of cross-hole hydraulic test in fractured granite. Groundwater, 44, 555-563.

Indian Census (2011) Total Population of Maheshwaram mandal, Ranga Reddy District. https://www.censusindia.co.in/subdistrict/Maheshwaram-mandal-rangareddy-andhrapradesh-4544. Accessed September 2008

Johnston, C. D. (1987). Preferred water flow and localised recharge in a variable regolith. Journal of Hydrology, 94(1-2), 129-142.

Krásný, J. \& Sharp Jr, J.M. (2007). Hydrogeology of fractured rocks from particular fractures to regional approaches: State-of-the-art and future challenges. Groundwater of Fractured Rocks. Taylor \& Francis Group, 1-32.

Lachassagne, P., Wyns, R., \& Dewandel, B. (2011). The fracture permeability of hard rock aquifers is due neither to tectonics, nor to unloading, but to weathering processes. Terra Nova, 23, 145-161.

Lerner, D.N., Issar, A.S. \& Simmers, I. (1990). Groundwater Recharge: A Guide to Understanding and Estimating Natural Recharge, Vol. 8, 99-228. Hannover: Heise.

Maréchal, J.C., Dewandel, B., Ahmed, S. \& Lachassagne, P. (2007). Hard rock aquifers characterization prior to modelling at catchment scale: an application to India. Groundwater in fractured rocks, IAH Selected Papers, 9, 1-30.

Maréchal, J.C., Dewandel, B., Ahmed, S., Galeazzi, L. \& Zaidi, F.K. (2006). Combining the groundwater budget and water table fluctuation methods to estimate specific yield and natural recharge. J Hydrol, 329, 281-293. 
Maréchal, J.C., Dewandel, B. \& Subrahmanyam, K. (2004). Use of hydraulic tests at different scales to characterize fracture network properties in the weathered- fractured layer of a hard rock aquifer. Water Resources Research, 40, W11508.

Maréchal, J.C., Galeazzi, L., Dewandel, B., \& Ahmed, S. (2003). Importance of irrigation return flow on the groundwater budget of a rural basin in India. International Association of Hydrological Sciences, Publication, 278, 62-67.

Mizan, S.A., Ahmed, S. \& Selles, A. (2019) Spatial estimation of groundwater storage from a 2D specific yield in the crystalline aquifer of the Maheshwaram watershed. J Earth Syst Sci (2019) 128: 185. https://doi.org/10.1007/s12040-019-1218-2.

Nicolas, M., Bour, O., Selles, A., Dewandel, B., Bailly-Comte, V., Chandra, S., Ahmed, S., \& Maréchal, J. C. (2019). Managed Aquifer Recharge in fractured crystalline rock aquifers: impact of horizontal preferential flow on recharge dynamics. Journal of Hydrology, 573, 717-732.

Nicolas, M. (2019). Impact of heterogeneity on natural and managed aquifer recharge in weathered fractured crystalline rock aquifers - Insights from two instrumented sites at different scales (south India). PhD Thesis, Université Rennes 1.

Nolan, B. T., Healy, R. W., Taber, P. E., Perkins, K., Hitt, K. J., \& Wolock, D. M. (2007). Factors influencing ground-water recharge in the eastern United States. Journal of Hydrology, 332(1-2), 187-205.

Omorinbola, E.O. (1983). Shallow seismic investigation for location and evaluation of groundwater reserves in the weathered mantles of the Basement Complex in southwestern Nigeria. Geoexploration, 21, 73-86.

Omorinbola, E.O. (1982). Verification of some geohydrological implications of deep weathering in the Basement Complex of Nigeria. Journal of Hydrology, 56, 347-368.

Owoade, A. (1995). The potential for minimizing drawdowns in groundwater wells in tropical aquifers. Journal of African Earth Sciences, 20, 289-293.

Perrin, J., Ferrant, S., Massuel, S., Dewandel, B., Maréchal, J.C., Aulong, S. \& Ahmed, S. (2012). Assessing water availability in a semi-arid watershed of southern India using a semi-distributed model. Journal of Hydrology, 460, 143-155.

Praamsma, T., Novakowski, K., Kyser, K., \& Hall, K. (2009). Using stable isotopes and hydraulic head data to investigate groundwater recharge and discharge in a fractured rock aquifer. Journal of Hydrology, 366(1-4), 35-45.

Rangarajan R, Athavale RN. 2000. Annual replenishable ground water potential of Indiaan estimate based on injected tritium studies. Journal of Hydrology 234: 38-53. 

Illinois. Illinois state water survey, Report of investigation, 40, 40.

Shah, T. (2007). The groundwater economy of South Asia: an assessment of size, significance and socio-ecological impacts. The Agricultural Groundwater Revolution:

Development.

https://ageconsearch.umn.edu/bitstream/158009/2/H039669.pdf.

Shokri, N., \& Salvucci, G. D. (2011). Evaporation from porous media in the presence of a water table. Vadose Zone Journal, 10(4), 1309-1318.

Sukhija, B.S., Nagabhushanam, P. \& Reddy, D.V. (1996). Groundwater recharge in semiarid regions of India: an overview of results obtained using tracers. Hydrogeology Journal, $4,50-71$.

Taylor, R. \& Howard, K. (2000). A tectono-geomorphic model of the hydrogeology of deeply weathered crystalline rock: evidence from Uganda. Hydrogeology Journal, 8, 279294.

Thiéry, D., Amraoui, N. \& Noyer, M.L. (2018). Modeling flow and heat transfer through unsaturated chalk-Validation with experimental data from the ground surface to the aquifer. Journal of Hydrology, 556, 660-673.

Thiéry, D. (1990). Logiciel MARTHE. Modélisation d'Aquifère par un maillage Rectangulaire en régime Transitoire pour le calcul hydrodynamique des écoulements, version 4.3. (Aquifer modeling with a transient rectangular mesh for the hydrodynamic flow calculation, version 4.3.) BRGM Report, 4S/EAU R32210, BRGM, Orleans, France.

USDA (1999) Soil taxonomy, A basic system of soil classification for making and interpreting soil surveys. https://www.nrcs.usda.gov/Internet/FSE_DOCUMENTS/nrcs142p2_051232.pdf.

Vigaud, N., Vrac, M. \& Caballero, Y. (2013). Probabilistic downscaling of GCM scenario over southern India. International Journal of climatology, 33:1248-1263

Wellings, S. R., \& Cooper, J. D. (1983). The variability of recharge of the English Chalk aquifer. Agricultural Water Management (Netherlands).

Wright, E.P. (1992). The hydrogeology of crystalline basement aquifers in Africa. Geological Society, London, Special Publications, 66, 1-27.

Wyns, R., Gourry, J.C., Baltassat, J.M. \& Lebert, F. (1999, September). Caractérisation multiparamètres des horizons de subsurface $(0-100 \mathrm{~m})$ en contexte de socle altéré (Multiparameter characterization of subsurface horizons $(0-100 \mathrm{~m})$ in an altered basement context). In $2 e$ Colloque GEOFCAN, BRGM, IRD, UPMC (pp. 105-110).

Wyns, R., Baltassat, J.M., Lachassagne, P., Legchenko, A., Vairon, J., \& Mathieu, F. (2004). Application of SNMR soundings for groundwater reserves mapping in weathered basement rocks, Brittany, France, Bull. Soc. Géol. France, 175, 21-34. 
Zhang, Z., Wang, W., Gong, C., Wang, Z., Duan, L., Yeh, T. C. J., \& Yu, P. Evaporation from seasonally frozen bare and vegetated ground at various groundwater table depths in the Ordos Basin, Northwest China. Hydrological Processes.

\section{Figure captions}

Figure 1. a,b. Location, geological map (IFP: Indo-French piezometer) and c topographic elevation map (masl: metre above sea level) of the study area (Maheshwaram watershed; $53 \mathrm{~km}^{2}$ ).

Figure 2. Weathering profile of the Maheshwaram area (modified after Dewandel et al., 2006).

Figure 3. (a) Empirical linear relation between pumping (Q) and rainfall at watershed scale. (b) Total estimated pumping (Q) with average water level (masl: metres above sea level) at watershed scale. (c) Histogram of pumping ratio for Nov13-May14 dry and Nov07-May08 dry at cell size. (d) Mean water level elevation map (red cross mark is showing the observation well), with average groundwater abstraction ( $\mathrm{mm} / \mathrm{season}$, blue dots) of all years at $685 \times 685$ scale.

Figure 4. (a) Histograms and (b) variogram analyses for estimated specific yield $\left(S_{y}\right)$ values for each depth interval of saprolite and fissured layer.

Figure 5. Average vertical $S_{y}$ variations in the weathering profile at watershed scale.

Figure 6. Rainfall-recharge relationship at watershed scale and plotted recharge trend from Dewandel et al. (2010).

Figure 7. Spatial distribution of total average (Avg.) recharge of Maheshwaram watershed at $685 \times 685 \mathrm{~m}$ cell size for years 2011 to 2015 .

Figure 8. Linear relationships of rainfall-recharge at watershed scale $(685 \mathrm{~m} \times 685 \mathrm{~m})$ with respect to (a) slope and (b) intercept. (c) Histogram showing rainfall-recharge correlation coefficient.

Figure 9. Calculated vs. Observed groundwater level elevation (Head) for each season.

Figure 10. Calibrated water level (WL) from 2011 to 2016, and projected water level from 2020 to 2039 with climate and groundwater abstraction variability. 
Figure 11. Interpretation of flowmeter measurements (19 wells) according to the saprolite-fractured layer interface (modified from Dewandel et al., 2006). (a) Fracture density; (b) Equivalent hydraulic conductivity of weathering profile (c) Hydraulic conductivity of conductive fracture zone $\left(K_{\mathrm{cfz}}\right)$; (d) Quality of observation expressed as the ratio between available observations for each aquifer zone and total 19 flowmeter tests. Data are integrated every $5 \mathrm{~m}$.

Figure 12. (a) Soil map of Maheshwaram watershed (modified from Condappa 2005) (b) Box and Whisker plots for recharge distribution among soils within the watershed.

Figure 13. Water-level elevation map. (a) Scenario 1, consecutive bad monsoons (June 2025) (b) Scenario 2, 10\% decrease in rainfall (June 2025), (c) Scenario 3, 10\% increase in rainfall, (d) Scenario 1 , frequent good monsoon (June 2031).

\section{Table}

Table 1. Irrigation return flow coefficient (from Dewandel et al. 2008; Maréchal et al., 2006)

\begin{tabular}{|c|c|c|}
\hline Land use & $\begin{array}{l}\text { Return flow coefficient: } \\
\text { Rabi }\end{array}$ & $\begin{array}{l}\text { Return flow coefficient: } \\
\text { Kharif }\end{array}$ \\
\hline Rice & 0.48 & 0.51 \\
\hline Vegetables & 0.24 & 0.26 \\
\hline Fruits & 0 & 0.2 \\
\hline Domestic & 0.2 & 0 \\
\hline
\end{tabular}

Note. Rabi: dry season; Kharif: rainy season.

Figure 1. 
(a)

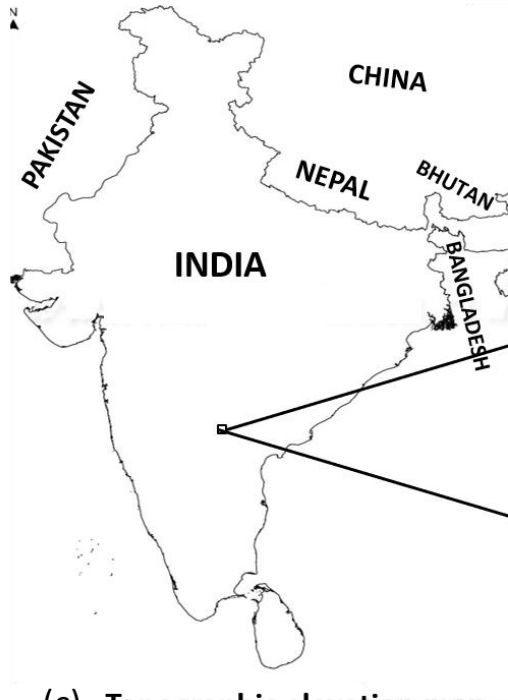

(c) Topographic elevation map

952

953

954

Figure 2. (b) Geological map

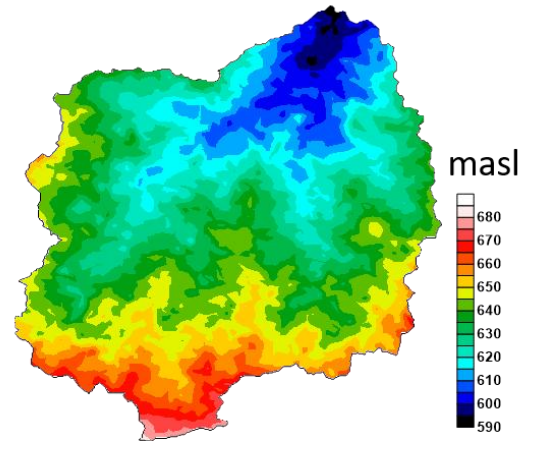

Quartvein

\section{Legend}

$\triangle \mathrm{IFP}$

$\triangle$ Road

Villages

Water Tank

Alluvium

Geology

Biotite granite

Biotite granite with pegmatite and leucogranite dykes

Leucocratic granite

Doleritic dyke 


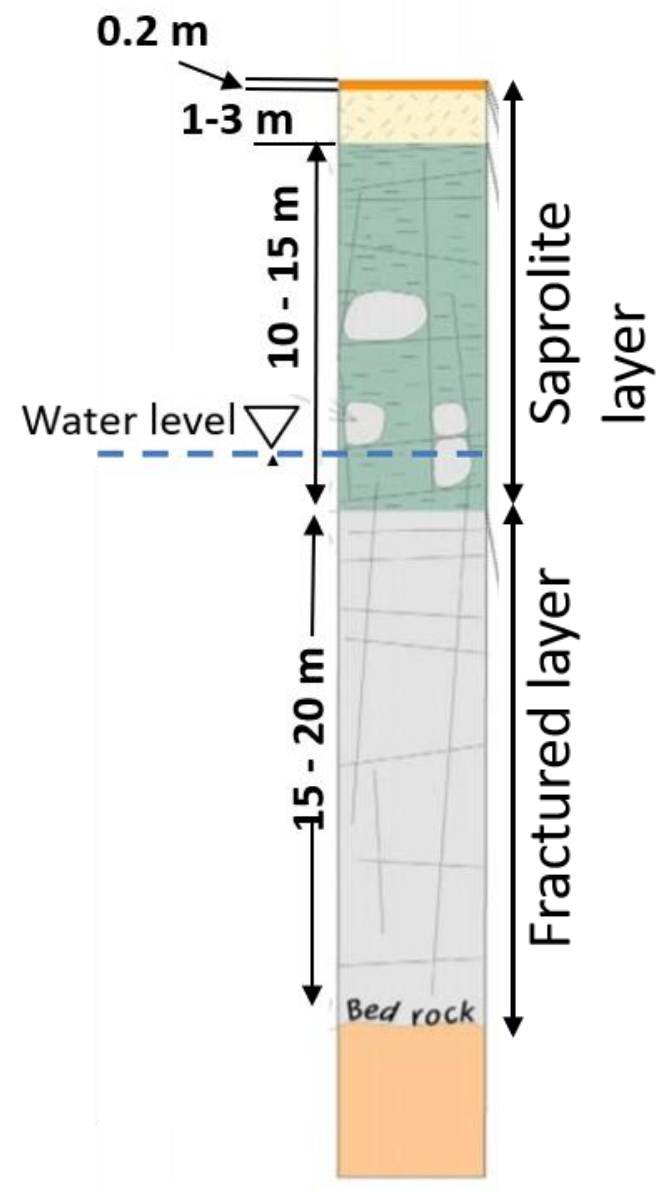

$956 \quad$ Figure 3.

957 

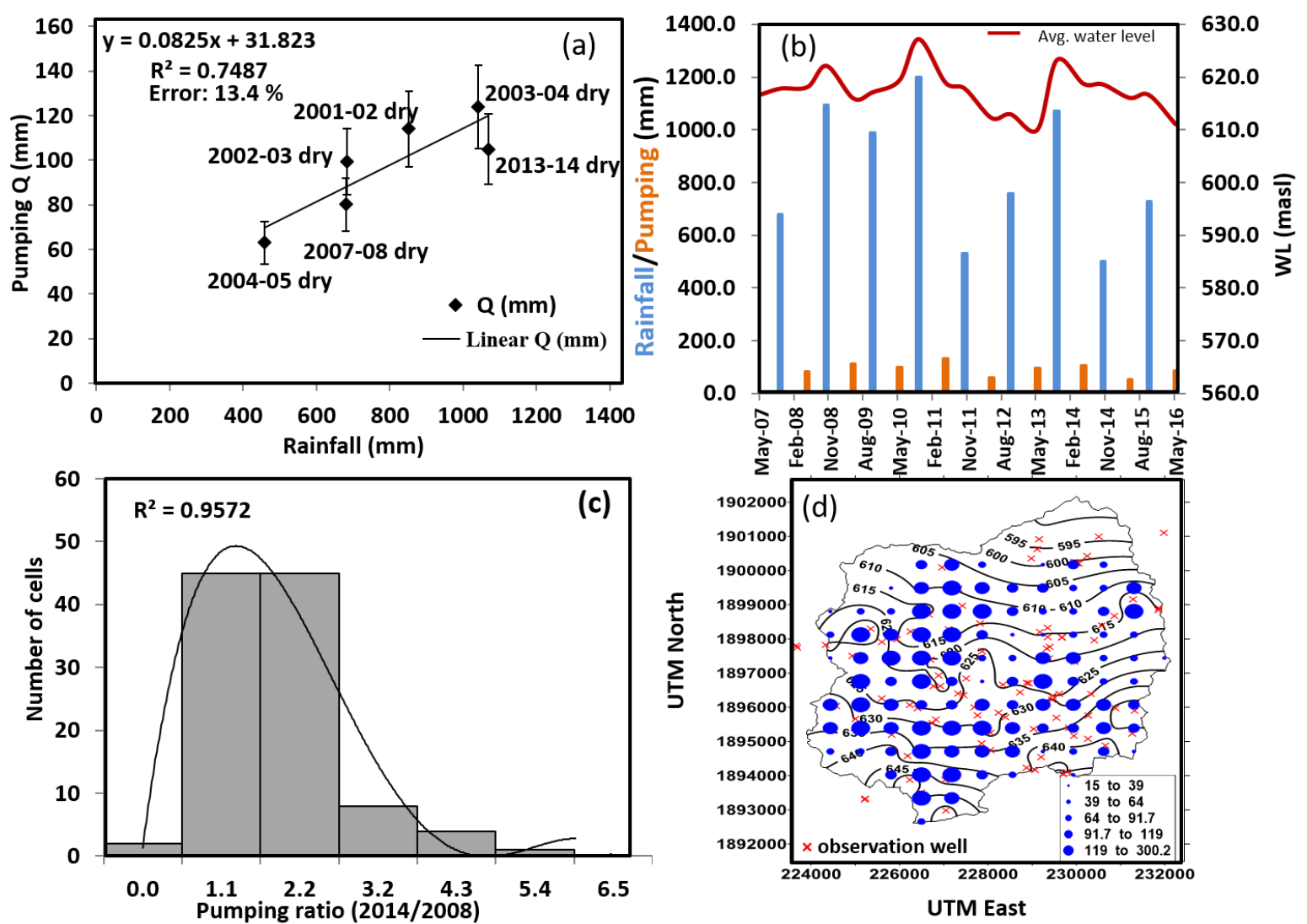

Figure 4.

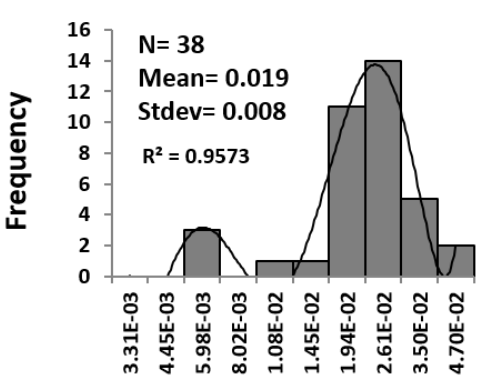

$s_{\mathrm{y}}$

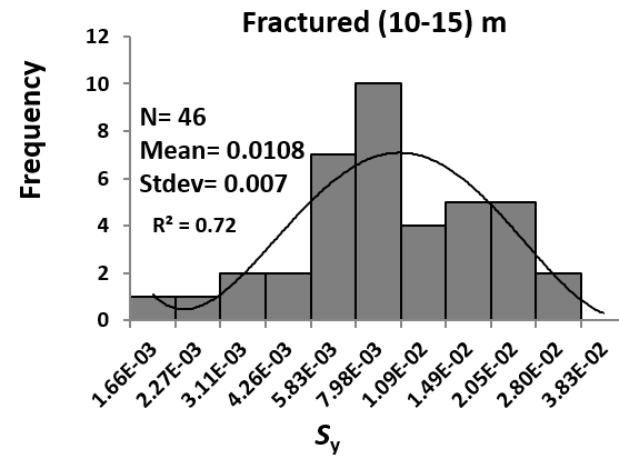

$\mathrm{N}=73$

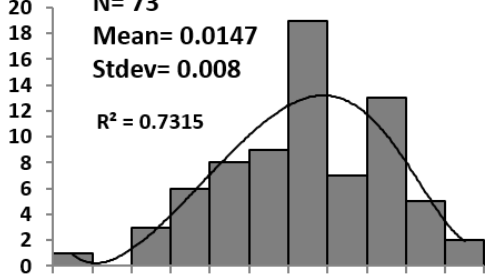

m o m

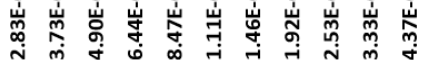

$S_{y}$

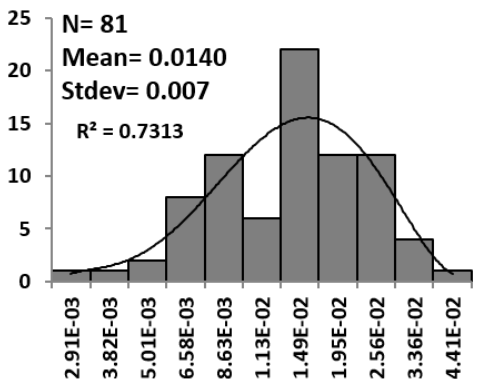

$S_{\mathrm{y}}$

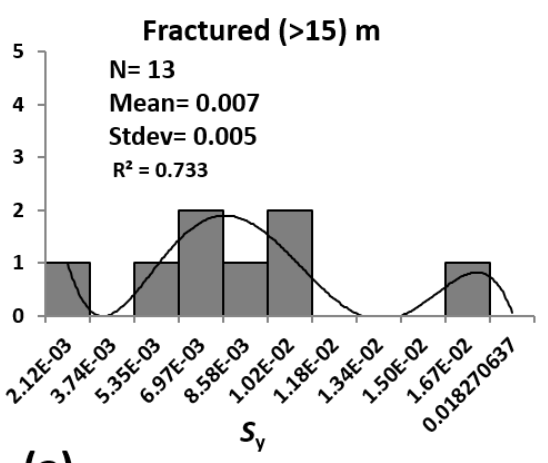

(a) 

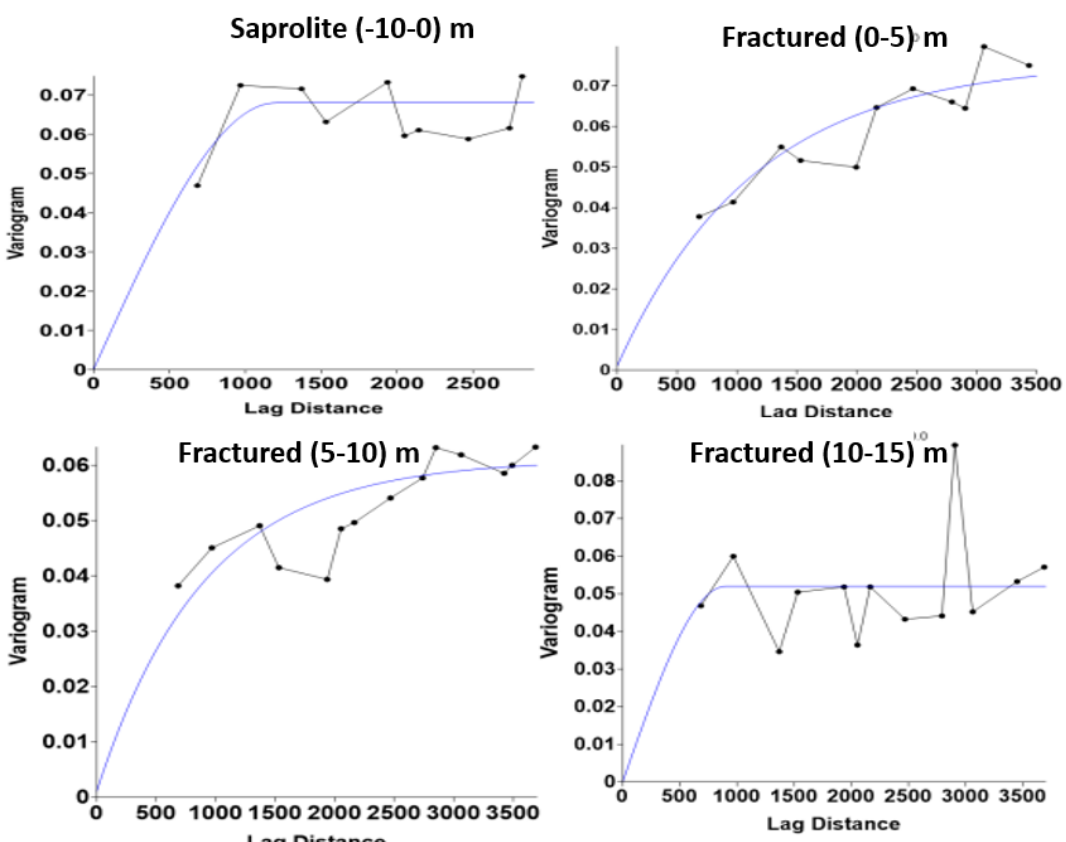

(b)

Figure 5. 


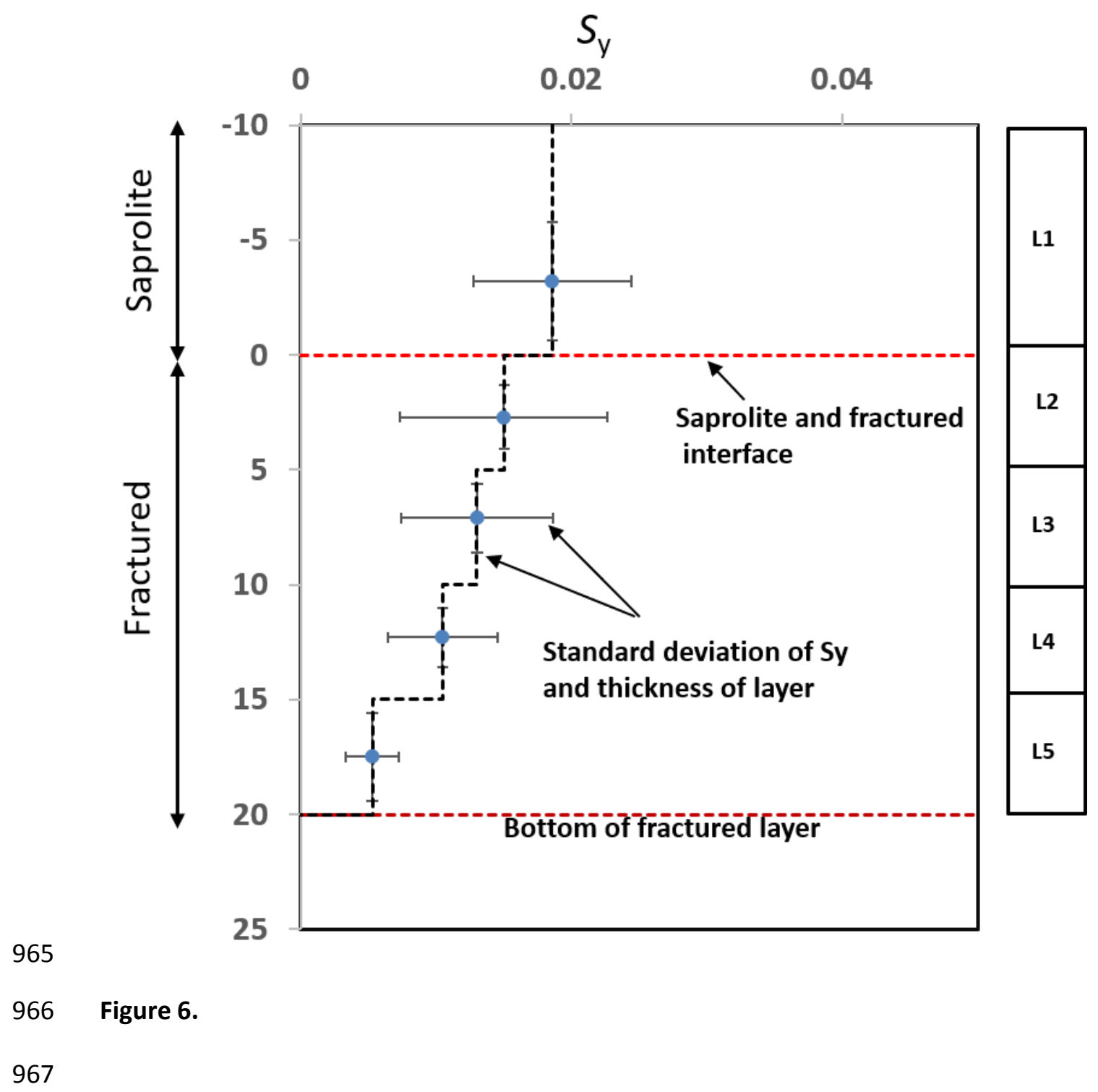




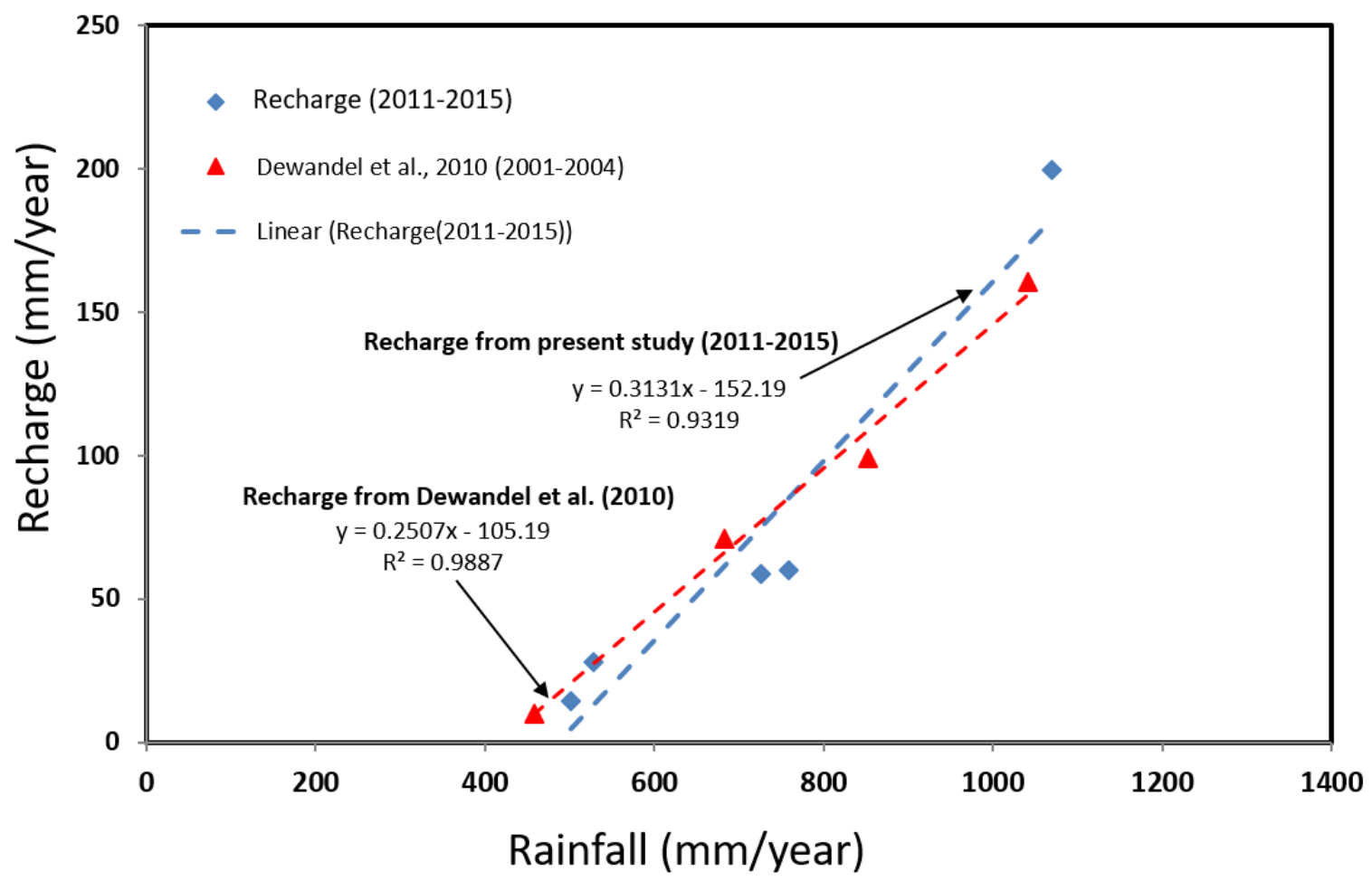

968

Figure 7.

970
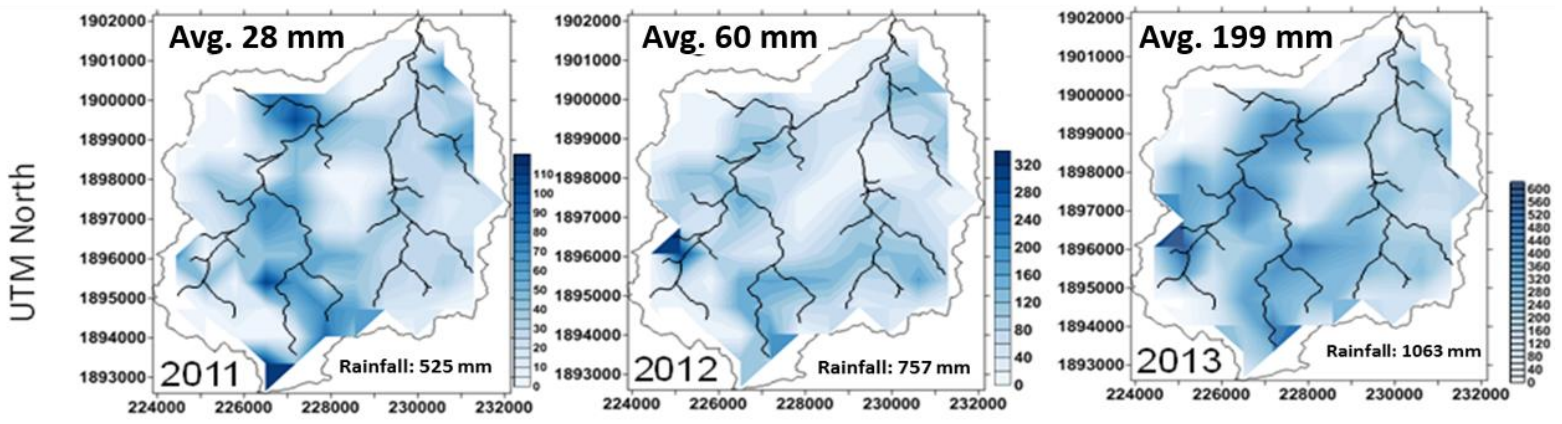

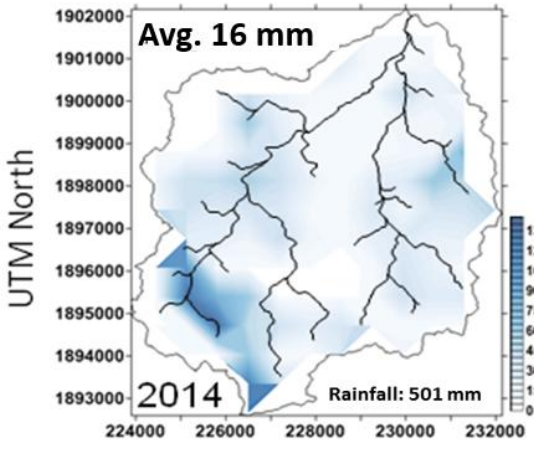

UTM East

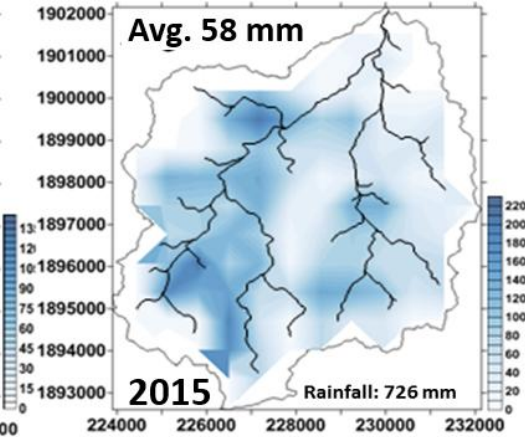

UTM East

Figure 8. 
(a) Slope

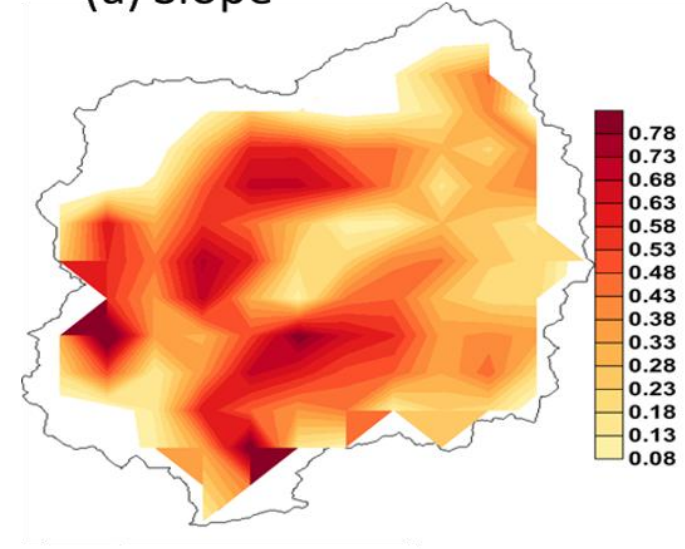

(c)
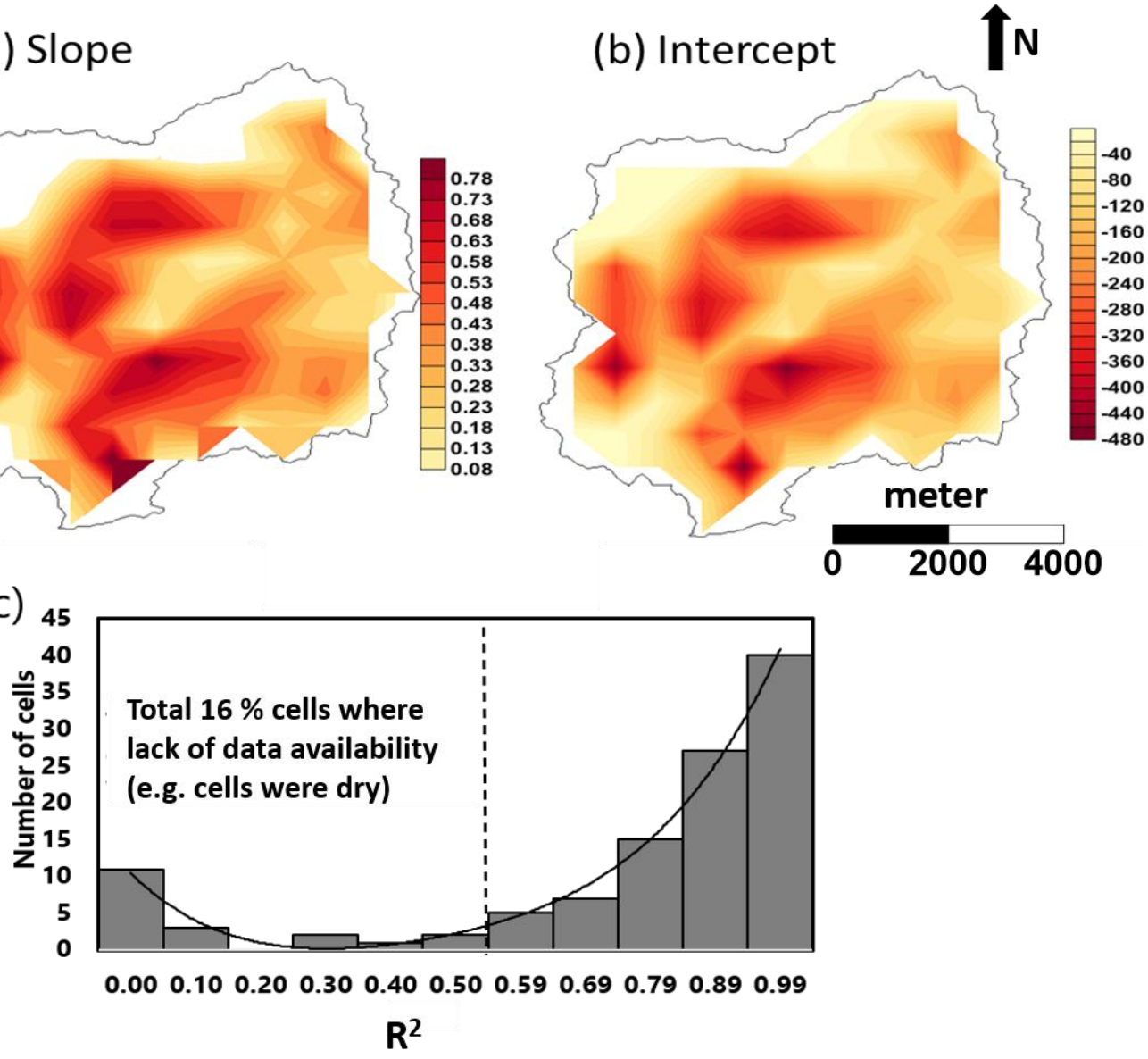

974

$975 \quad$ Figure 9. 

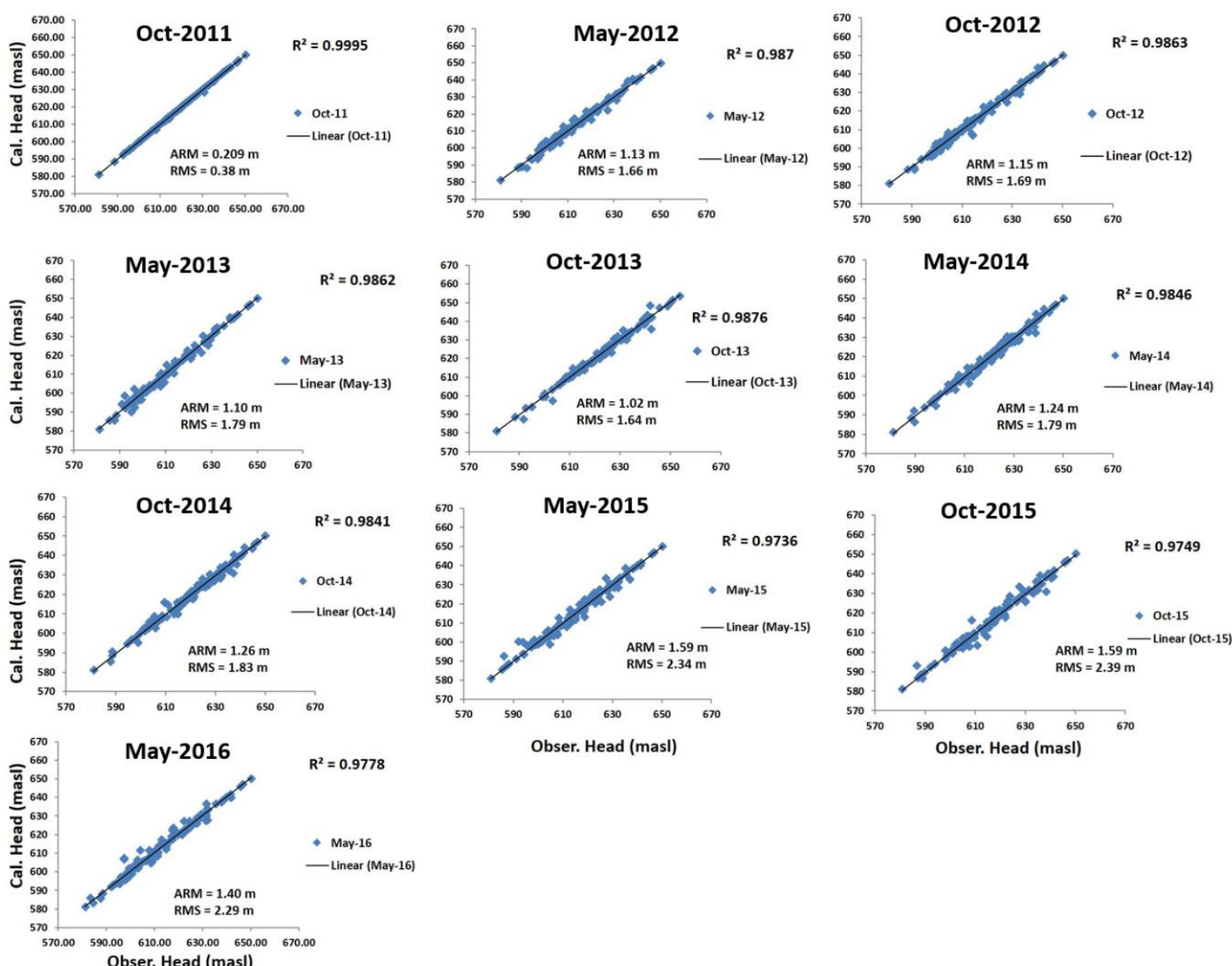

977 Figure 10.

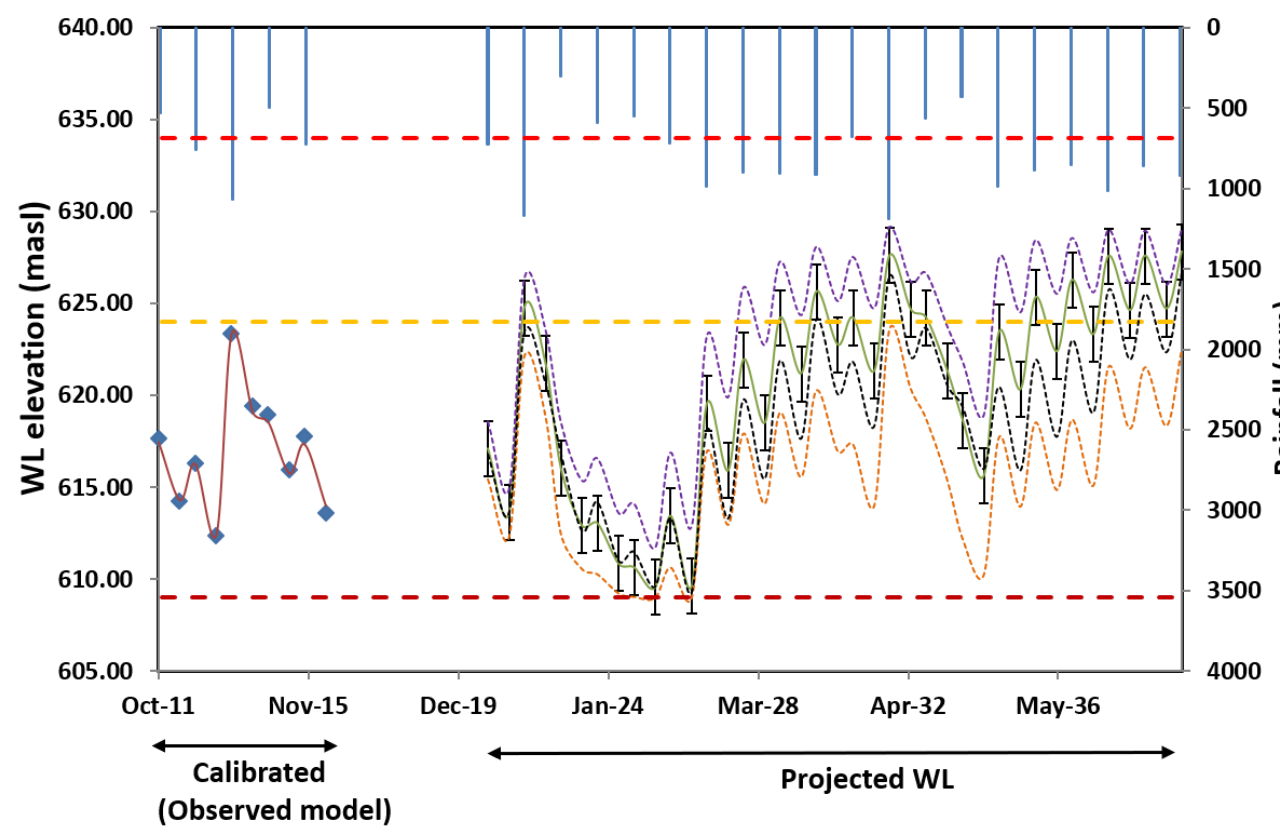

Rainfal

Observed WL

Calculated WL

Scenario 1

ह ------Scenario 2

----- Scenario 3

- Topo elevation

Saprolite

elevation

- - Basement

Figure 11. 


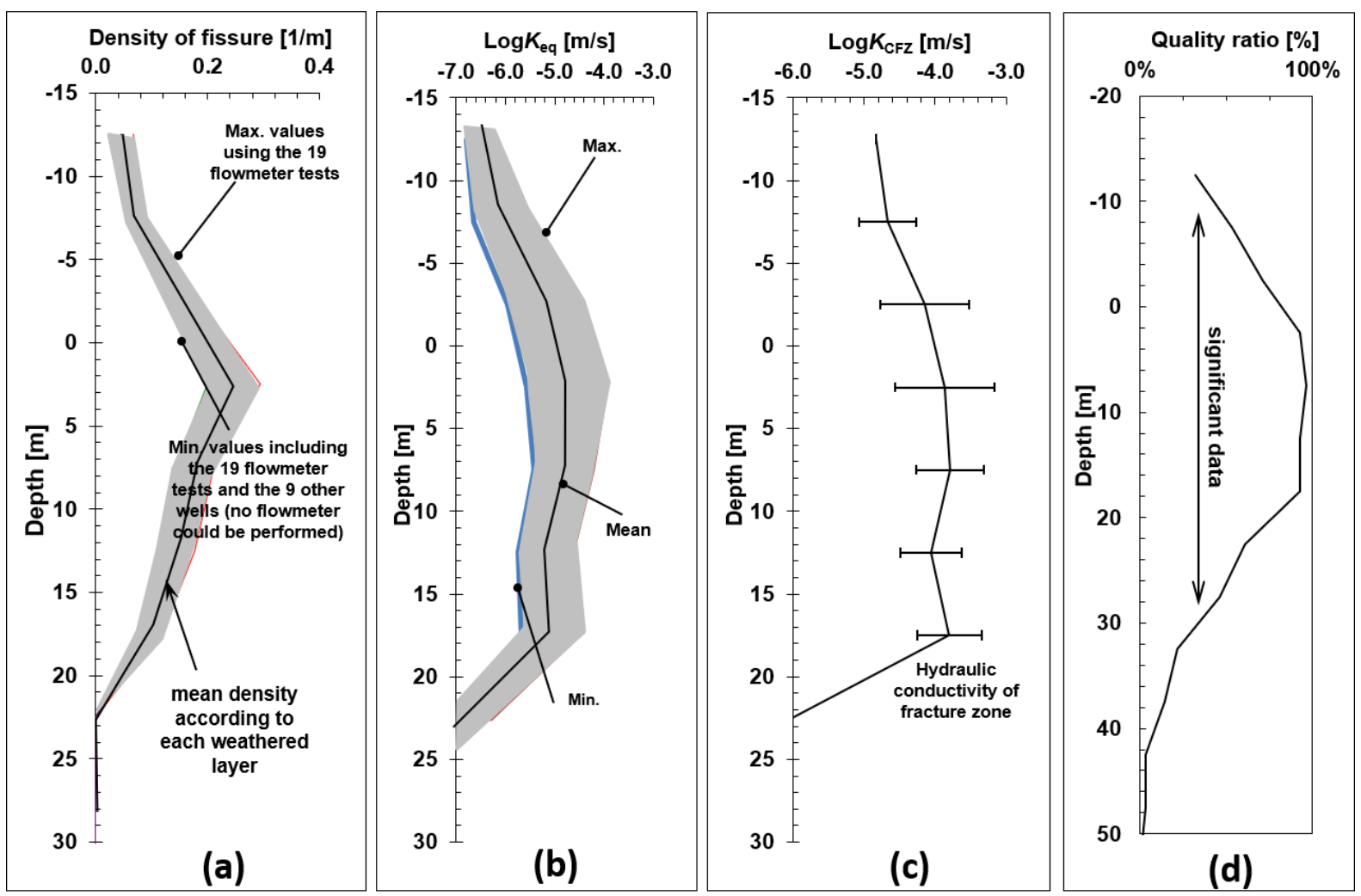

982

Figure 12.

984
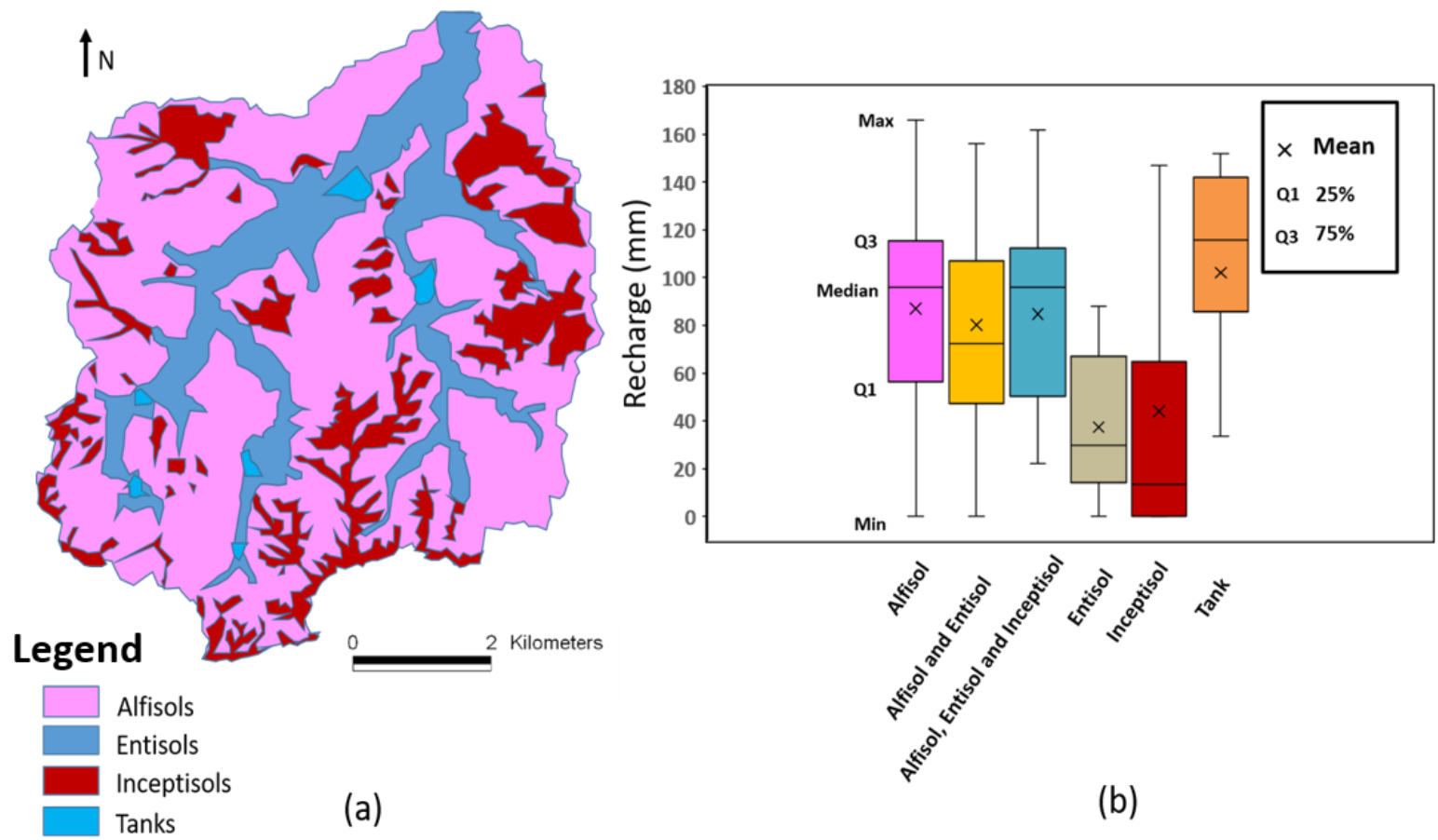

Figure 13. 
(a)

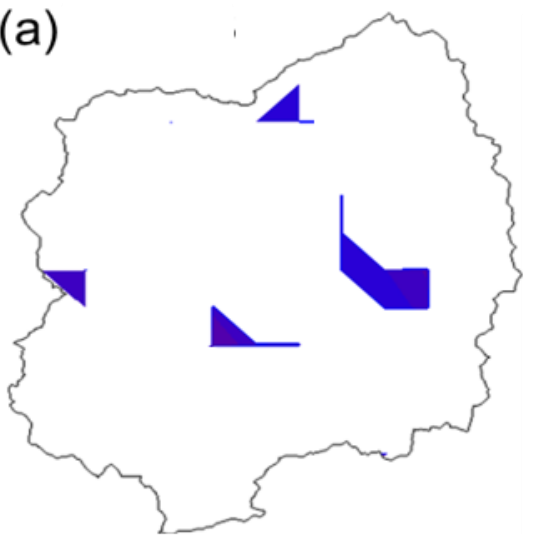

(c)

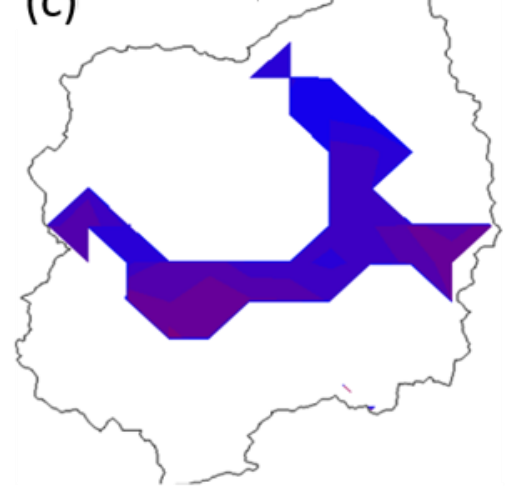

(b)

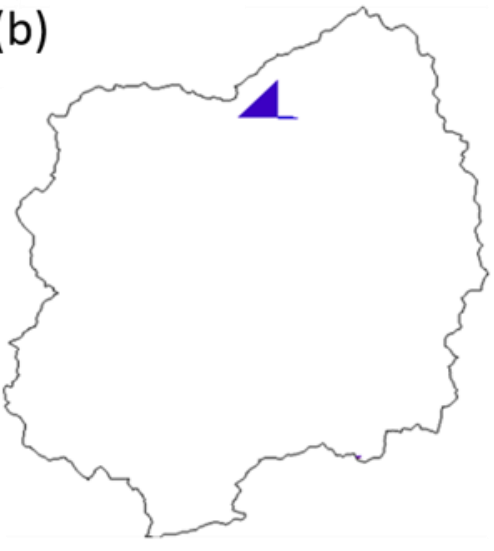

(d)

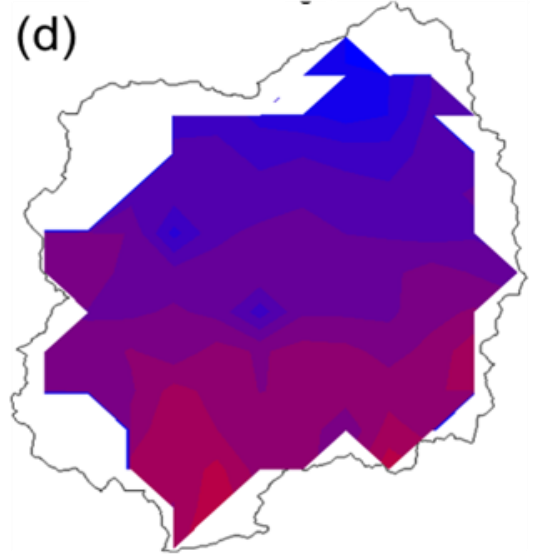

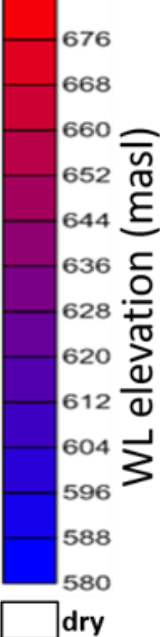

988

989 
990

991

Supplemental figures

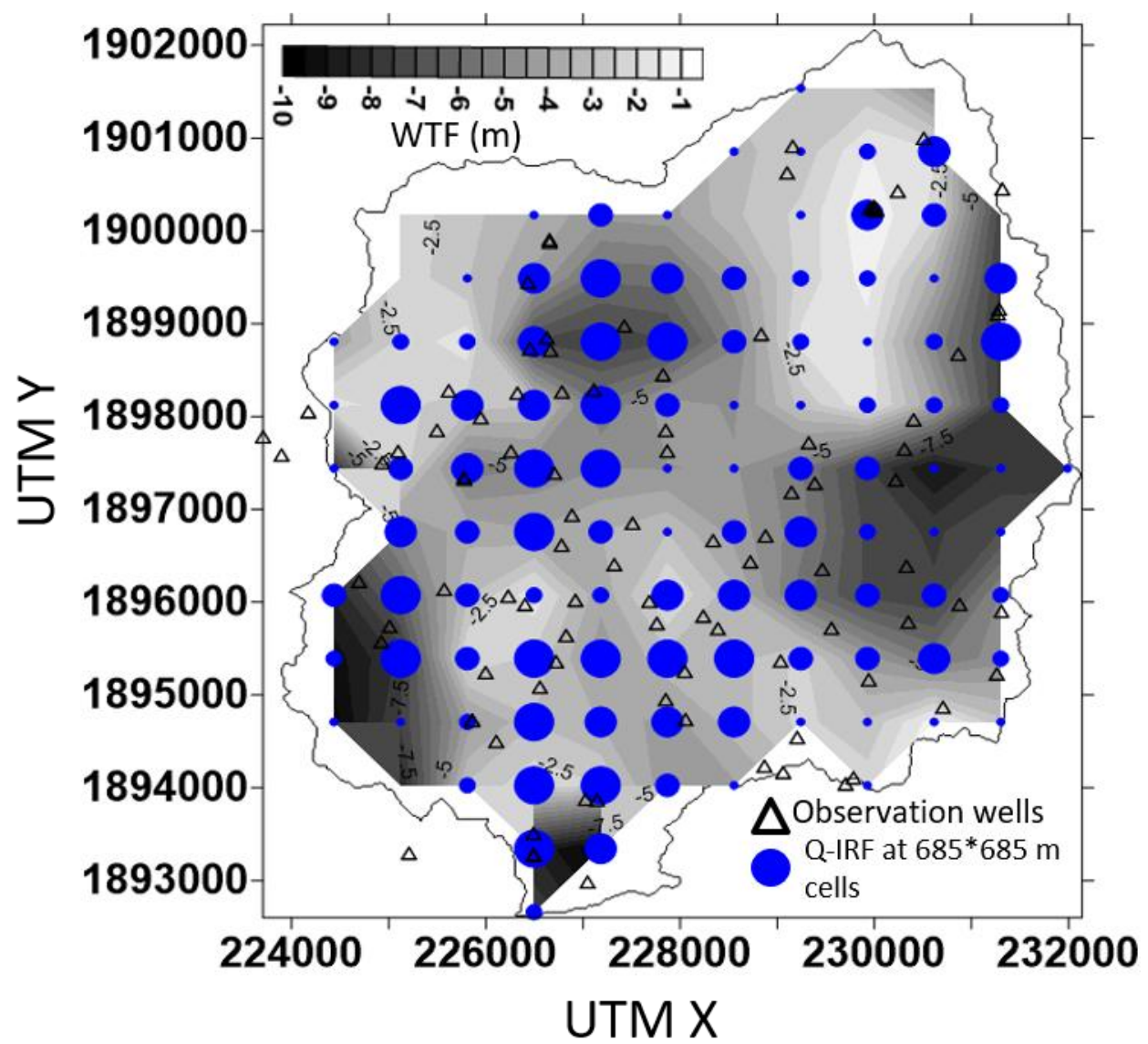

992

993

994

995

996

997
Figure S1. Average water table fluctuation map for all years ( 85 observation wells). Aggregation of QIRF on grid with $685 \times 685 \mathrm{~m}$ cells shown as dot-proportional ( 0.05 inch) values. 

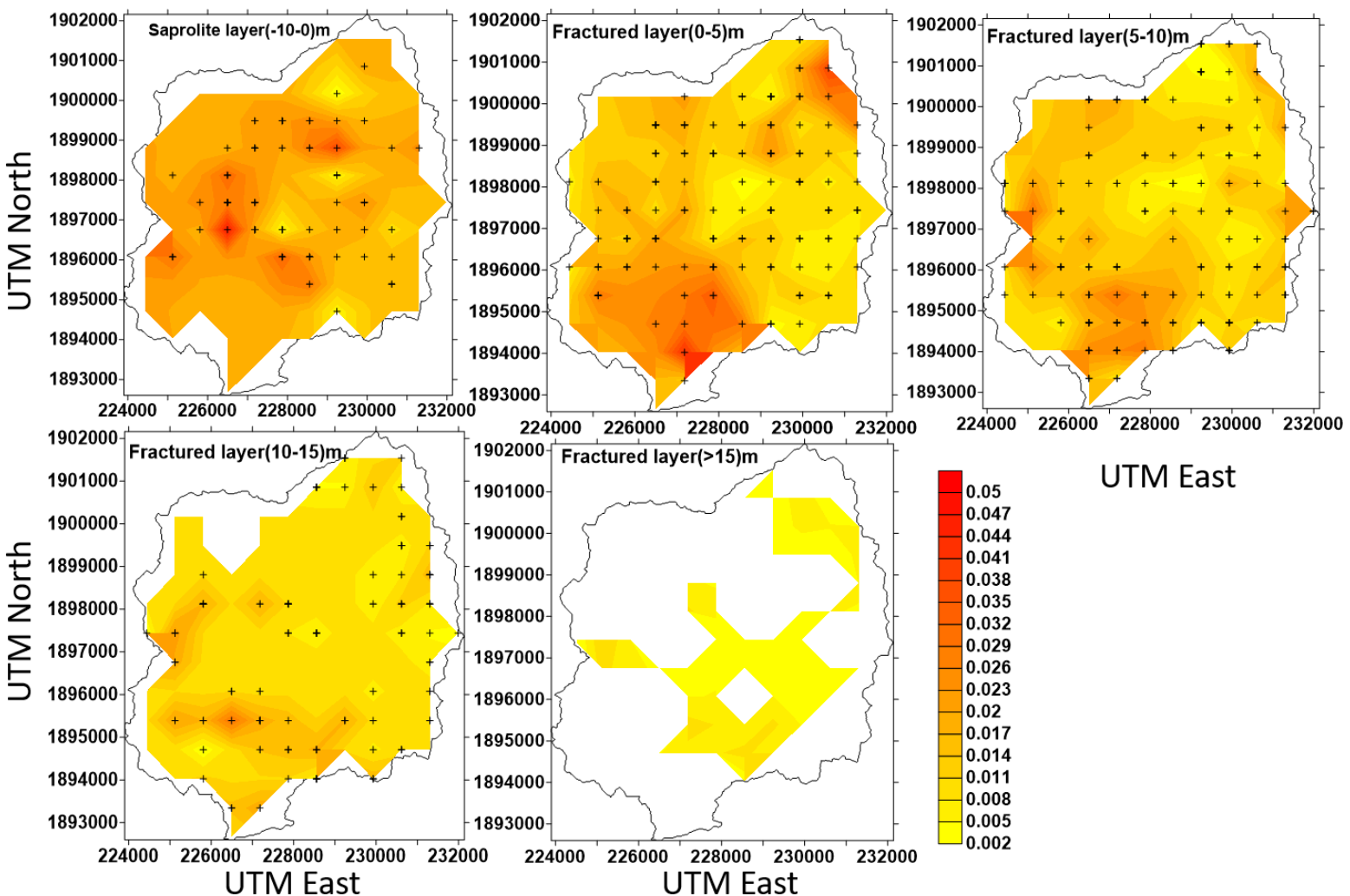

UTM East

998

999

1000

1001

1002

1003

1004

1005

1006

1007

1008

1009

1010

1011

1012

1013

1014

1015

1016

Figure S2. Sy vs. depth intervals in weathering profile for the Maheshwaram watershed (one for saprolite layer and four for the fractured layer).

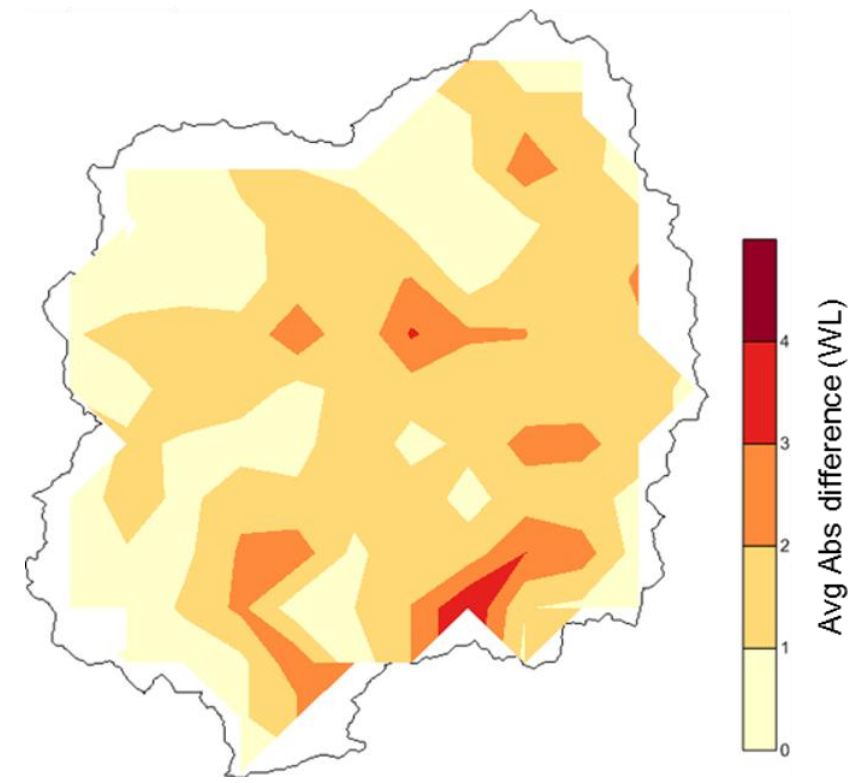

Figure S3. Average spatial map of absolute residual difference of piezometric level for all years. 


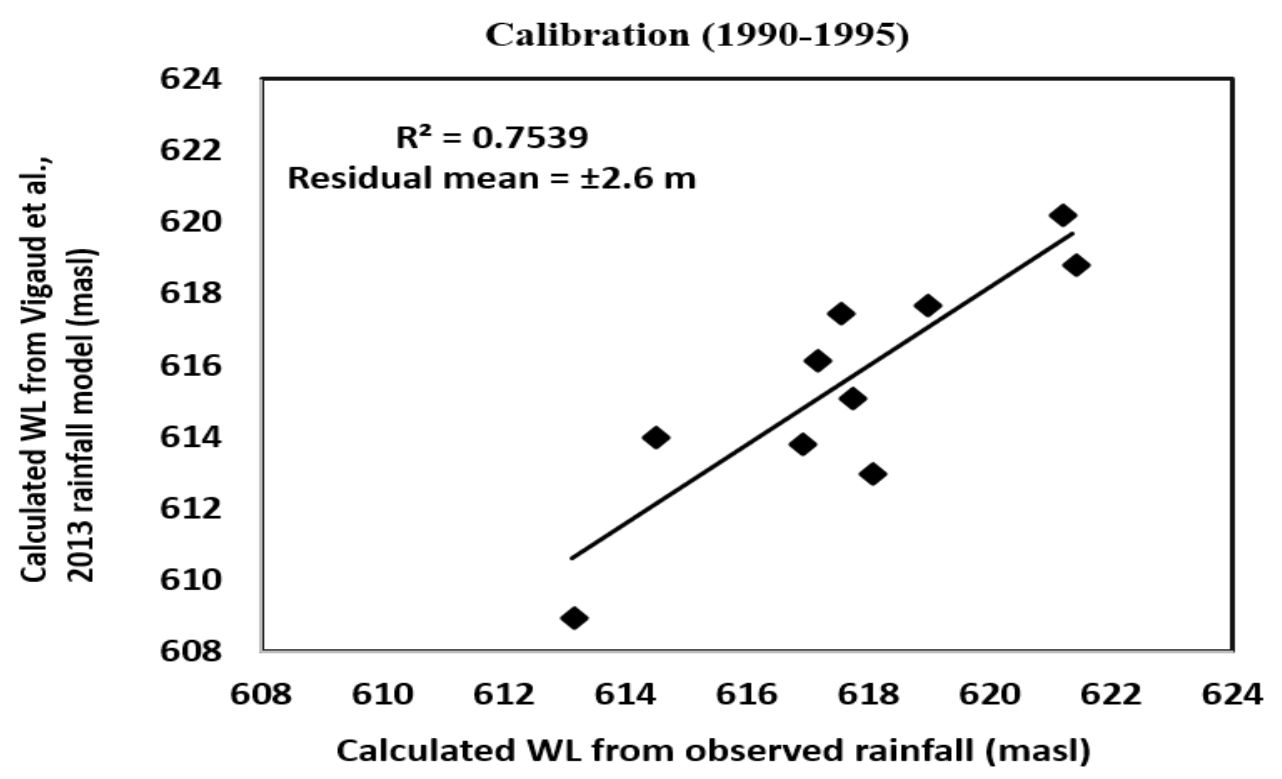

Figure S4. Calibration of the Vigaud et al. (2013) downscaled rainfall.

1020

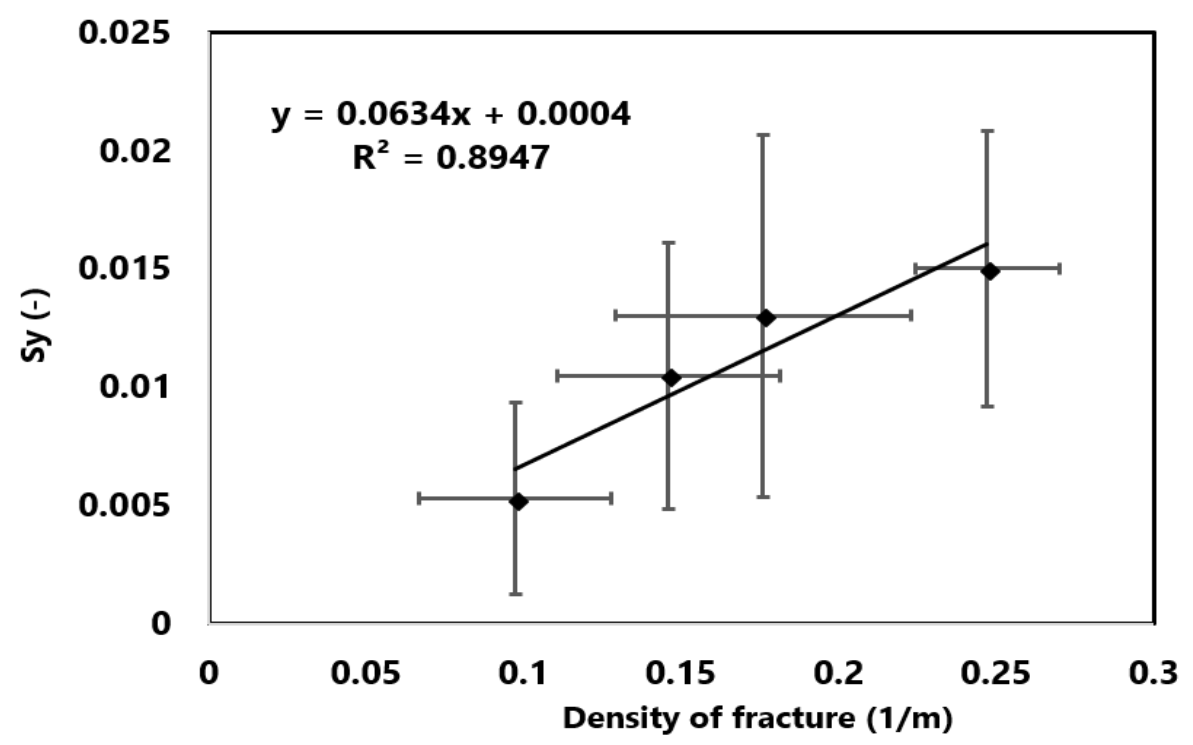

1021

1022

Figure S5. Linear relation between Sy and fracture density (df).

1023

1024

1025

1026 